\title{
Drainage of subduction interface fluids into the forearc mantle evidenced by a pristine jadeitite network (Polar Urals)
}

\author{
Samuel Angiboust $^{1}$ (D) | Johannes Glodny ${ }^{2}$ ｜ Aitor Cambeses $^{1,3}$ ｜ Tom Raimondo $^{4}$ | \\ Patrick Monié $^{5}$ | Michael Popov ${ }^{6,7}$ | Antonio Garcia-Casco ${ }^{3,8}$
}

\footnotetext{
${ }^{1}$ Institut de Physique du Globe de Paris, Université de Paris, Paris, France

${ }^{2}$ GFZ German Research Centre for Geosciences, Potsdam, Germany

${ }^{3}$ Department of Mineralogy and Petrology, Faculty of Sciences, University of Granada, Granada, Spain

${ }^{4}$ UniSA STEM, University of South Australia, Adelaide, Australia

${ }^{5}$ Géosciences Montpellier, Université de Montpellier, UMR-CNRS, Montpellier, France

${ }^{6}$ Institute of Geology and Geochemistry, Ural Branch, Russian Academy of Sciences, Yekaterinburg, Russia

${ }^{7}$ Russia Ural State Mining University, Yekaterinburg, Russia

${ }^{8}$ Instituto Andaluz de Ciencias de la Tierra, CSIC-Universidad de Granada, Granada, Spain
}

\section{Correspondence}

Samuel Angiboust, Université de Paris, Institut de Physique du Globe de Paris, F-75005 Paris, France.

Email: angiboust@ipgp.fr

\section{Funding information}

Agence Nationale de la Recherche, Grant/ Award Number: 16C538

Handling Editor: Katie Evans

\begin{abstract}
The physical and mechanical processes rooted in the hydrated, serpentinized mantle above subduction zones remain insufficiently explored despite fundamental implications for our understanding of rheology and fluid recycling along subduction interfaces. Through a field-based investigation, serpentinized peridotites and jadeitite samples from a fossil forearc mantle in the Polar Urals (Russia) are studied here to document fluid-rock interaction processes in the high- $P$ field, as well as the long-term evolution of the base of the mantle wedge. Petrographic, geochemical and microstructural observations reveal a complex, protracted evolution of the jadeitite-forming fluid pathway throughout the gradual cooling of the forearc mantle and increasing serpentinization of the host. It is shown that the jadeitite lenses in the studied locality (a) derive for a large part from a trondhjemitic dyke earlier emplaced in a warm subduction environment, and (b) record the cooling of the subduction hangingwall under high- $P$ conditions associated with increasing host serpentinization. In the studied locality, the majority of the jadeitites formed at relatively high temperatures $\left(>600^{\circ} \mathrm{C}\right)$ by the influx of $\mathrm{Na}-\mathrm{Al}$-rich, slab-derived metamorphic fluids that were drained along the base of the mantle wedge, parallel to the subduction interface. Changes in bulk-rock geochemical signatures and in paragenetic sequences also constrain the compositional evolution of the fluid channelized along this drainage, with an increasing sedimentary component. The phlogopite-bearing walls of the dyke exhibit $\mathrm{Rb}-\mathrm{Sr}$ and $\mathrm{Ar}-\mathrm{Ar}$ ages ranging between c. 405 and c. $390 \mathrm{Ma}$, a range partly overlapping within uncertainty with the previously dated zircons from the jadeitite core (410- $400 \mathrm{Ma}$; U-Pb). This study opens a unique window on the pristine structures formed above the plate interface by melting and fluid-rock interaction in the early subduction stages, as well as their evolution during secular cooling of the base of the mantle wedge.
\end{abstract}

\section{K E Y W O R D S}

fluids, jadeite, mantle wedge, serpentinite, subduction 


\section{1 | INTRODUCTION}

Understanding the pathways of subduction fluids produced by devolatilization reactions within the downgoing plate is of paramount importance to volatile budget and recycling, as well as the rheology of the plate interface (Bebout \& Penniston-Dorland, 2016; Hyndman \& Peacock, 2003; Prigent et al., 2018; Scambelluri et al., 2019; Schmidt \& Poli, 2014). The release of crustal fluids into the overlying mantle wedge is known to (a) create a variably serpentinized 'cold nose' at temperatures $<650^{\circ} \mathrm{C}$ and (b) lower the mantle solidus and generate partial melting at temperatures $>700^{\circ} \mathrm{C}$ (Abers et al., 2017; Grégoire et al., 2008; Grove et al., 2012; Poli \& Schmidt, 2002; Rüpke et al., 2004; Spandler \& Pirard, 2013; Worzewski et al., 2011). The physical nature of early fluid-rock interaction processes in the mantle wedge region of subduction zones remains insufficiently documented because most of known natural exposures from the base of the mantle wedge have been substantially overprinted during long-lasting subduction and exhumation (e.g. Agard et al., 2018). Some studied occurrences comprise the Cuba-Dominican Republic serpentinitic mélanges (e.g. Krebs et al., 2011; Lazaro et al., 2011) and the Ladakh suture zone in northern India (e.g. Bouilhol et al., 2012; Guillot et al., 2001). The nature and origin of another potential mantle wedge 'cold nose' section located in the Sambagawa belt in Japan remains a matter of debate (Aoya Endo et al., 2013; Kugimiya \& Takasu, 2002). Most of these localities, which commonly exhibit incomplete sections, have been overprinted during exhumation and therefore only preserve a limited fraction of the mantle wedge section. Long-lasting subduction-related serpentinization events also largely erased most of the markers from the early subduction stages, markers only occasionally preserved as dismembered blocks in 'serpentinite mélanges' (e.g. Gerya et al., 2002; Lazaro et al., 2009; Sorensen et al., 2010). It is important to note that such mélanges, despite their great geodynamic importance, may not be considered fully representative of the nature of the subduction interface hangingwall in active subduction environments because of their long-lasting, protracted tectonic history (except perhaps for some recent, well-documented settings such as in the Marianas forearc mantle wedge; e.g. Tamblyn et al., 2019). This paradox may also explain the discrepancy between the nearly complete serpentinization degree of exhumed 'mélanges' and the relatively moderate estimates calculated by seismological studies based on the perturbation of seismic wave velocities (between 10 and 40 vol.\% hydration, for most present-day settings; Abers et al., 2017).

Jadeitites are locally found in serpentinite mélange settings (together with blueschists and eclogites), and commonly interpreted as an evidence of fluid-rock interaction in the subduction channel (e.g. Tsujimori \& Harlow, 2012). Indeed,
Harlow and Sorensen (2005) and Harlow et al. (2015) have emphasized in their seminal review papers the importance of jadeitite bodies as markers of major fluid conduits in the (partly) serpentinized mantle above the plate interface. The pioneering observations of Bleeck (1908), Coleman (1961) and Harlow (1994) among others demonstrate that Na-AlSi-rich fluids precipitate as vein-filling material from upward-moving slab-derived fluids. Yet, the vast majority of the tectonic settings on which this genetic model is based on (e.g. Myanmar, Guatemala) exhibit very discontinuous exposures or even remobilized jadeitite boulders found along streams. We thus critically need more in situ observation of jadeitites in their formation environment as well as on structural relationships between jadeitites and their host peridotites (e.g. Sorensen et al., 2010). One of the few places on Earth where such pristine contact can be observed lies along the Main Uralian Thrust (MUT) in the Polar Urals, Russia (Dobretsov \& Ponomareva, 1968; Meng et al., 2011; Figure 1). In this contribution, we focus on the Syum-Keu massif, and reconstruct through a petrochronological and geochemical study the evolution of this important jadeitite deposit. We highlight how these findings fill a critical gap in our current understanding about fluid transfer into the mantle wedge.

\section{2 | GEOLOGICAL BACKGROUND}

The Palaeo-Uralian oceanic realm was located between the East European and Siberian cratons during early Palaeozoic times and comprised at least one intra-oceanic island arc (called Magnitogorsk arc in the Southern Urals; e.g. Queiroga et al., 2016; Savelieva et al., 2002; Stampfli et al., 2002 and references therein). Later, the East European continental margin entered into the Uralian subduction zone from upper Devonian to Carboniferous times (Brown et al., 2006; Glodny et al., 2004; Ivanov, 2001; Puchkov, 2009). In the Polar Urals, this collisional event led to the formation of a stack of continental nappes with East European margin affinity which are now overlain by a large nappe of partly serpentinized peridotites (namely the Syum-Keu, Rai-Iz and Voikar massifs; Figure 1a). The MUT (Figure 1a), which can be traced over 2,000 km along the Urals belt (Dobretsov \& Sobolev, 1984), juxtaposes these three peridotite massifs with the underlying metamorphosed Timanian-age (late Neoproterozoic to Cambrian) continental margin of East European affinity (e.g. the Marun-Keu complex; Glodny et al., 2004; Meng et al., 2020; Udovkina, 1971). In the Polar Urals, the MUT exhibits a complex tectono-metamorphic history encompassing a main prograde and a moderate retrograde structural overprint (Sichev \& Kulikova, 2012). A recent finding reporting an occurrence of garnet peridotite showing peak burial conditions $>3.5 \mathrm{GPa}$ (Selyatitskii \& Kulikova, 2017) in the 
FIGURE 1 (a). Geological map of the Polar Urals showing the three ultramafic massifs mentioned in the text, separated of the underlying $H P$ metamorphic units (continental crust and local remnants of blueschist facies ophiolites) by the Main Ural Thrust (in red). Green spots localize jadeitite localities mentioned in the literature. Note that these jadeitites bodies occur in a similar structural position, above the MUT and in the lowermost part of the Syum-Keu/Voikar/Rai-Iz peridotitic massifs (e.g. Dobretsov \& Ponomareva, 1968).

(b) Detailed geological map of the study area showing in the background the serpentinization rate (based on the mapping from Kuznetsov et al., 1986, completed by our chemical whole-rock analyses), as well as the location of the jadeititebearing serpentinized network. All studied samples come from the place labelled "main deposit" $65^{\circ} \mathrm{E}$
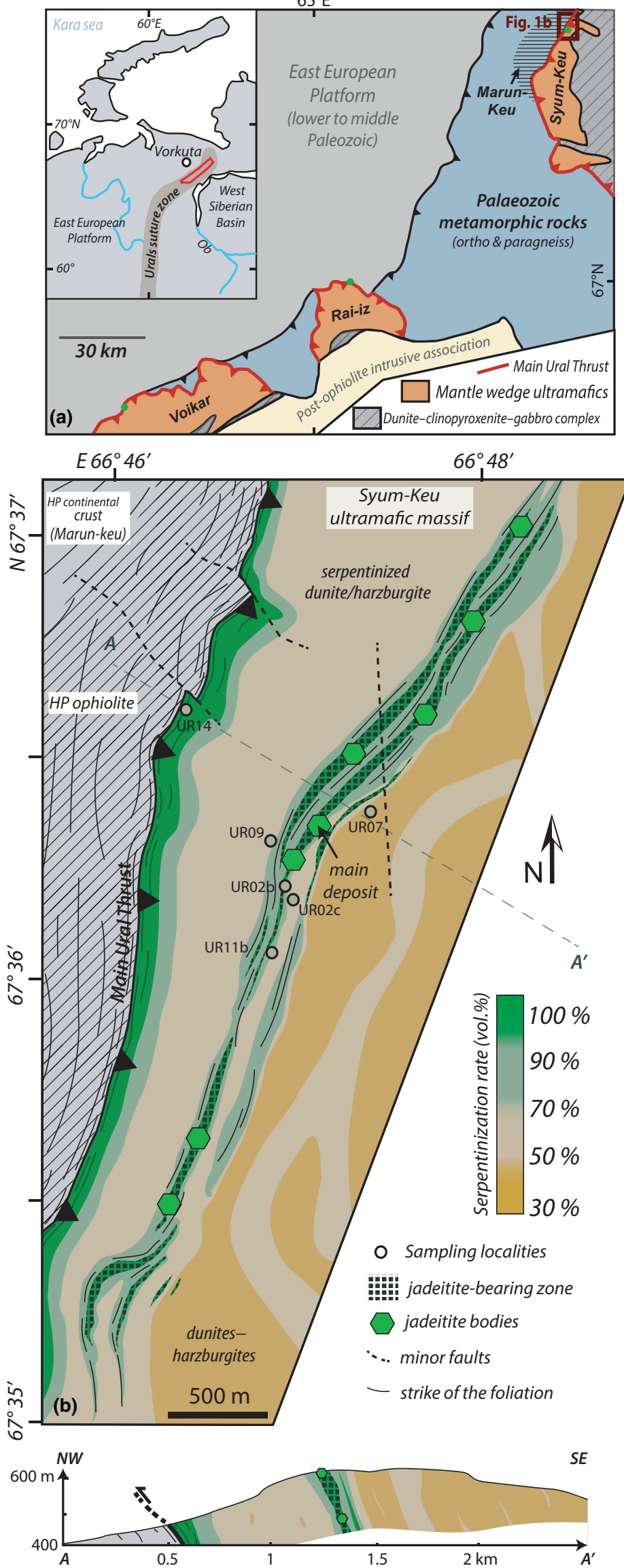
Marun-Keu complex contrasts with other estimates pointing to relatively shallower burial conditions $(1.6-1 \mathrm{w} 2.1 \mathrm{GPa})$ in a rather hot subduction environment $(600-\mathrm{w}] 700^{\circ} \mathrm{C}$; Liu et al., 2019; Molina et al., 2002). This apparent discrepancy, together with the wide lithological diversity encountered in the field, may support the idea that the Marun-Keu complex is constituted by a stack of tectonic slices with different pressure-temperature $(P-\mathrm{w}] T)$ histories. Eclogite facies metamorphism in this complex has been dated between 375 and [w] $359 \mathrm{Ma}$ (Sm-Nd mineral isochron method: Shatsky et al., 2000) and 366-w $358 \mathrm{Ma}(\mathrm{Rb}-\mathrm{Sr}$ multi-mineral method; Glodny et al., 2003; ages recalculated using the updated IUGS recommendation for the ${ }^{87} \mathrm{Rb}$ decay constant, cf. Villa et al., 2015).

Sandwiched between the metamorphosed East European crust and the three peridotite massifs (Figure 1a), the remnants from the oceanic subduction stage (palaeo-accretionary complex) are rare in the Polar Urals and only exposed as mafic lenses and cherts wrapped by metasediments or serpentinite schists below the MUT (e.g. Figure 1b). High- $P$ minerals such as glaucophane and jadeite (e.g. Kazak et al., 1976; Kuznetsov et al., 1986; ' $H P$ ophiolite' in Figure 1b) are witnesses of a high-P/low- $T$ (HP-w] $L T)$ context typical of a subduction environment. The three overlying peridotite massifs, locally transformed to antigorite schists in the vicinity of the MUT (Figure 1b), are mostly harzburgitic in nature (Savelieva \& Suslov, 2014 and references therein). They exhibit large chromite deposits and are cross-cut by numerous dunitic channels interpreted as the melt extraction pathways (Batanova et al., 2011). Some domains have undergone intense ductile deformation during the formation of oceanic lithosphere (Savelieva \& Suslov, 2014). Most authors consider the Rai-Iz, Syum-Keu and Voikar peridotite massifs as representative of a supra-subduction setting, providing a unique opportunity for evaluating the processes rooted at the base of an inferred Devonian-Carboniferous island arc (e.g. Batanova et al., 2011; Savelieva et al., 2002, 2007, 2016). It is indeed clear that the MUT hangingwall exhibits all the characteristics expected for the base of a mantle wedge including (a) a serpentinization gradient and (b) the presence of jadeite veins in the hangingwall, above a $H P-W T$ metamorphic imprint in the footwall (e.g. Batanova et al., 2011; Dobretsov \& Ponomareva, 1968; Glodny et al., 2003; Meng et al., 2016; Shmelev, 2011).

\section{3 | FIELD RELATIONSHIPS AT THE STUDIED LOCALITY}

The study area is located on the western flank of the SyumKeu massif in the Pus'yerka locality, north of the intersection between the MUT and the Bolshaya Xadata river (Figures $1 \mathrm{~b}$ and 2a). Previous field investigations have revealed the presence of (a) serpentinized shear zones along and above the MUT (Kuznetsov et al., 1986) and (b) N-S to NE-SWstriking jadeite-bearing lenses embedded in the serpentinized dunite-harzburgite host (Fishman, 2006; Meng et al., 2011, 2016; Figure 1b). The regional foliation in the serpentinized host is generally parallel with the MUT structures. The serpentinization ratio estimated from field, geochemical and density measurements reveal a background regional value of 35 wis 65 vol.\% (in line with the 45 wis 65 vol.\% estimates from Makeyev, 1992), with locally up to $90 \%$ w] $100 \%$ along the MUT and within the studied jadeite-bearing networks (Figure 1b; Table S1).

The serpentinized, jadeite-bearing domains mostly comprise antigorite schists with minor amounts of brucite, magnetite and phlogopite (Makeyev, 1992) as well as chlorite, tremolite and magnesite. The main jadeitite-bearing serpentinized network is between 50 and $300 \mathrm{~m}$ thick, dips 50 Ww $70^{\circ}$ to the $\mathrm{E}$ and is located $\sim 1 \mathrm{~km}$ above the main thrust, that is, the palaeo-subduction interface (see cross-section in Figure 1b). It pinches out and transforms into a narrow jadeitite-free domain in the north and in the south of the mapped area (Figure 1b). Inside this shear zone, tens of whitish jadeitite lenses, elongated parallel with the main foliation direction, are observed (Figure $2 b$ ). The mining of this jadeitite deposit in the 1980s enables a good structural description of the jadeitites and their relationships with their host. Jadeitite lens thickness ranges from several tens of centimetres to almost $2 \mathrm{~m}$ in the few places where the lenses can be observed in situ. It can be deduced from the shape of excavations that some jadeitite bodies reached between 5 and $8 \mathrm{~m}$ in width in their thickest segments and were up to $100 \mathrm{~m}$ long (e.g. Kuznetsov et al., 1986; Meng et al., 2011). The pioneering work of Kuznetsov et al. (1986), which provides critical information about the structural relationships before extensive mining and destruction of the exposure, reports that the jadeitite lenses form an en echelon ribbon with their long axis parallel to the main serpentinized network (Figure 1b). Jadeitite bodies form a several-hundred metres long, dyke-like structure, which has been moderately boudinaged during ductile shearing in the host serpentinites (Figure 1b). Importantly, these authors also mention the presence of 'plagioclasite' remnants with variable jadeitization imprint in the centre and in the north of the deposit.

Jadeitite bodies' internal organization comprises (a) a white jadeite-rich core, (b) discontinuous mafic domains sharply separated from the white domains, and containing mm-sized intricate amphibole and phlogopite crystals, (c) cracks cutting through the jadeitite that contain phlogopitite, a blueish amphibole and an emerald-green Cr-rich clinopyroxene and (d) variably thick, sheared phlogopite-rich metasomatic rinds lining the margins of the jadeitite body with the host serpentinite (Figure 2b-d; see also Kuznetsov et al., 1986). We provide hereafter a petrographic description 

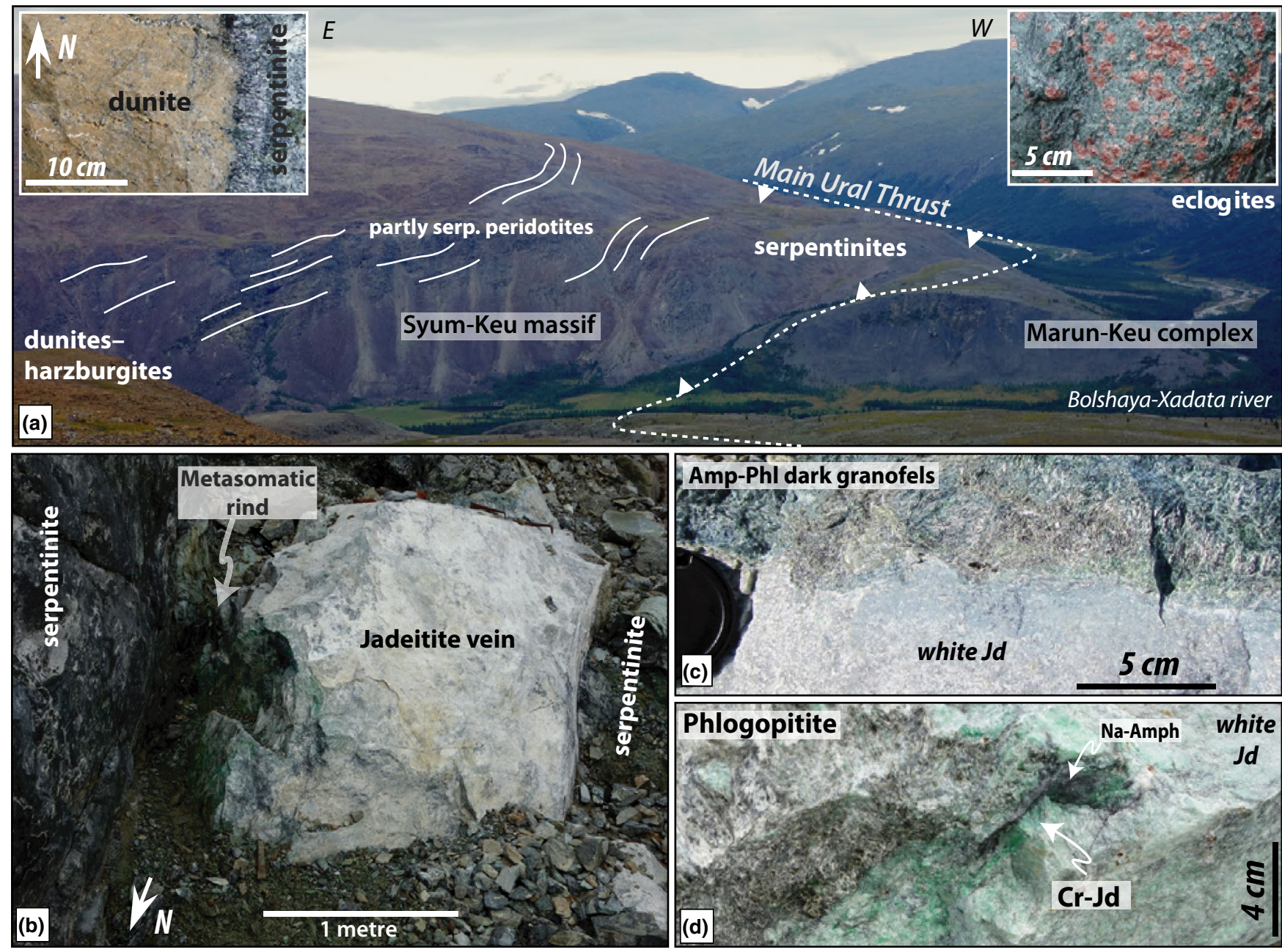

FI G URE 2 (a) Field view photographed $1 \mathrm{~km}$ south of the Pus'yerka jadeitite area showing the regional structure with the underlying MarunKeu complex overlain by the partly serpentinized peridotites from the Syum-Keu massif in which discontinuous pods of jadeitites are found, $\sim 1 \mathrm{~km}$ above the Main Ural Thrust. Inset pictures show (left) a serpentinized dunite along a fracture and (right) a typical eclogite as found in the $H P$ gneisses from the Marun-Keu complex. (b) View from one of the main jadeitite veins showing in situ relationships between the host serpentinites and the main jadeitite body. Jadeitite become gradually greener the closer it is to the contact with serpentinite. (c) Picture showing the contact between dark granofels and white jadeitite. (d) Picture showing a phlogopite-rich vein in which green Cr-jadeite and dark Na-amphibole have been observed (sample UR06)

of these four zones. Zircon crystals separated from the white jadeitite yielded SHRIMP U-Th-Pb ages of $404 \pm 7 \mathrm{Ma}$ (Meng et al., 2011) and $409 \pm 3.3$ Ma (Konovalov \& Sergeev, 2015), interpreted by Meng et al. (2011) as dating intra-oceanic subduction initiation within the Uralian ocean realm.

\section{\begin{tabular}{l|l}
4 & ANALYTICAL METHODS
\end{tabular}}

Quantitative mineral chemistry was obtained using a Cameca SX-5 Electron Probe operated at the CAMPARIS analytical facility in Paris University using standard analytical conditions $(15 \mathrm{keV}, 10 \mathrm{nA}$, beam diameter $5 \mu \mathrm{m})$, with a set of synthetic and natural crystals for calibration. The X-ray maps were acquired on the same instrument using analytical conditions of $15 \mathrm{keV}, 250 \mathrm{nA}$, a dwell time of $55 \mathrm{~ms}$ and a step size of $2 \mu \mathrm{m} . \mathrm{Fe}_{2} \mathrm{O}_{3}(\mathrm{Fe}), \mathrm{MnTiO}_{3}$ $(\mathrm{Mn}, \mathrm{Ti})$, diopside $(\mathrm{Mg}, \mathrm{Si}), \mathrm{CaF}_{2}(\mathrm{~F})$, orthoclase $(\mathrm{Al}$, $\mathrm{K})$, anorthite $(\mathrm{Ca})$ and albite $(\mathrm{Na})$ were used as standards. The X-ray images were processed and quantified with the DWImager software (R. L. Torres-Roldán \& A. García-Casco, unpublished data; García-Casco, 2007). A scanning electron microscope (SEM) Zeiss EVO MA10 at the Institut de Physique du Globe de Paris using internal calibration standards was used for microstructural observations and surface composition characterization. The X-ray fluorescence (XRF) measurements were performed at the GFZ Potsdam (see Table S1 for local compositions and details on XRF analytical procedure). Mineral abbreviations are after Whitney and Evans (2010). Clinopyroxene and clinoamphibole compositions are calculated according to 
the classification of Morimoto (1989) and Hawthorne and Oberti (2007) respectively. Atoms per formula unit is abbreviated apfu.

For $\mathrm{Rb}-\mathrm{Sr}$ mineral dating, two small, phlogopite-rich samples (less than $50 \mathrm{~g}$ ) were crushed for mineral separation work. $\mathrm{Rb}-\mathrm{Sr}$ isotopic data were generated at GFZ Potsdam on a Thermo Scientific TRITON thermal-ionization mass spectrometer. $\mathrm{Sr}$ isotopic composition was measured in dynamic multi-collection mode. $\mathrm{Rb}$ isotope dilution analysis was done in static multi-collection mode. The value obtained for ${ }^{87} \mathrm{Sr} /{ }^{86} \mathrm{Sr}$ in the NIST SRM 987 isotopic standard during the period of analytical work was $0.710242 \pm 0.000020(2 \sigma, n=16)$. For age calculation, standard uncertainties of $\pm 0.005 \%$ for ${ }^{87} \mathrm{Sr} /{ }^{86} \mathrm{Sr}$ and of $\pm 1.5 \%$ for ${ }^{87} \mathrm{Rb} /{ }^{86} \mathrm{Sr}$ ratios were assigned to the results. Individual analytical uncertainties were consistently smaller than these values. Mineral separating technique and analytical procedures are described in greater detail in Glodny et al. (2008). Uncertainties of isotope and age data are quoted at $2 \sigma$ throughout this work. The program ISOPLOT/EX3.71 (Ludwig, 2009) was used to calculate the regression lines. The ${ }^{87} \mathrm{Rb}$ decay constant is used as recommended by Villa et al. (2015).

The ${ }^{40} \mathrm{Ar} /{ }^{39} \mathrm{Ar}$ analyses were conducted in the Noble Gas laboratory of Géosciences at the University of Montpellier 2, France, using a multicollector mass spectrometer (Thermo Scientific Argus VI MS) with a nominal mass resolution of $\sim 200$ and a sensitivity for argon measurements of $3.55 \times 10^{-17}$ moles/fA at $200 \mu \mathrm{A}$ trap current. The mass spectrometer houses a Nier-type source and a fixed array of five Faraday detectors and one compact discrete dynode (CDD) detector. It is linked to a stainless steel gas extraction/purification line and $\mathrm{CO}_{2}$ laser system for step heating which produces after focusing a $1 \mathrm{~mm}$ diameter beam that is used for step heating. The four samples selected for dating were irradiated for $20 \mathrm{hr}$ in the core of the Triga Mark II nuclear reactor of Pavia (Italy) with several aliquots of the Taylor Creek sanidine standard $(28.34 \pm 0.10 \mathrm{Ma})$ as flux monitor. Argon isotopic interferences on $\mathrm{K}$ and $\mathrm{Ca}$ were determined from irradiation of $\mathrm{KF}$ and $\mathrm{CaF}_{2}$ pure salts from which the following correction factors were obtained: $\left({ }^{40} \mathrm{Ar} /{ }^{39} \mathrm{Ar}\right)_{\mathrm{K}}=0.00969 \pm 0.00038$, $\left({ }^{38} \mathrm{Ar} /{ }^{39} \mathrm{Ar}\right)_{\mathrm{K}}=0.01297 \pm 0.00045,\left({ }^{39} \mathrm{Ar} /{ }^{37} \mathrm{Ar}\right)_{\mathrm{Ca}}=0.000$ $7474 \pm 0.000021$ and $\left({ }^{36} \mathrm{Ar} /{ }^{37} \mathrm{Ar}\right)_{\mathrm{Ca}}=0.000288 \pm 0.00001$ 6. After loading in the sample chamber, the samples were baked at $\sim 120^{\circ} \mathrm{C}$ during $24 \mathrm{hr}$ to remove atmospheric argon from the sample surface. Air aliquots from an automated pipette system were analysed prior to the sample analyses to monitor mass discrimination and detector bias. Line blanks were analysed between every three sample analyses and were subtracted from succeeding sample data. Stepheating experiments on one to three mineral grains were conducted with a duration of heating of $60 \mathrm{~s}$ at each step. A custom-made software is used to control the laser intensity, the timing of extraction/purification and the data acquisition. The ARARCALC software $\odot$ v2.5.2 (Koppers, 2002) was used for data reduction and plotting. All the data were corrected for system blanks, radioactive decay, isotopic interferences and mass discrimination. Atmospheric ${ }^{40} \mathrm{Ar}$ is estimated using a value of the initial ${ }^{40} \mathrm{Ar} /{ }^{36} \mathrm{Ar}$ ratio of 298.6 (Lee et al., 2006). Plateau ages are defined as including $>50 \%$ of the total ${ }^{39} \mathrm{Ar}$ released, distributed over at least three contiguous steps, with ${ }^{40} \mathrm{Ar} * \beta^{39} \mathrm{Ar}$ ratios within agreement of the mean at the $95 \%$ confidence level. Calculated ages are reported at the $2 \sigma$ level and include uncertainties in the $J$-values.

The LA-ICP-MS trace element maps were acquired using a Resonetics M-50-LR $193 \mathrm{~nm}$ excimer laser coupled to an Agilent 7700x Quadrupole ICP-MS housed at Adelaide Microscopy, University of Adelaide. Instrument conditions and mapping protocols similar to that employed in this study are outlined in Raimondo et al. (2017). Preablation of each raster scan was completed to minimize the effect of redeposition ( $19 \mu \mathrm{m}, 75 \%$ overlap), followed by $15 \mathrm{~s}$ washout and $10 \mathrm{~s}$ of background measurement. A beam diameter of $19 \mu \mathrm{m}$, line spacing of $19 \mu \mathrm{m}$ and repetition rate of $10 \mathrm{~Hz}$ were employed for a green jadeitite sample PU2, resulting in an energy density of $3.5 \mathrm{~J} / \mathrm{cm}^{2}$ at the target. Standards were analysed in duplicate every $2 \mathrm{hr}$ during the mapping session, including reference glasses NIST 610 (Jochum et al., 2011; Pearce et al., 1997) and GSD-1D (Jochum et al., 2011). A beam diameter of $51 \mu \mathrm{m}$ was used for all standard analyses, and included five pre-ablation shots $(51 \mu \mathrm{m}, 75 \%$ overlap) followed by $20 \mathrm{~s}$ washout, $30 \mathrm{~s}$ background measurement and $40 \mathrm{~s}$ ablation time. Data acquisition was performed in time-resolved analysis mode as a single continuous experiment. Each analysis comprised a suite of 38 elements, and dwell times were as follows: $0.01 \mathrm{~s}(\mathrm{Li}), 0.002 \mathrm{~s}(\mathrm{Na}, \mathrm{Mg}, \mathrm{Al}, \mathrm{Si}, \mathrm{K}, \mathrm{Ca}, \mathrm{Mn}, \mathrm{Fe}, \mathrm{Ni}$ ), $0.005 \mathrm{~s} \mathrm{(Sc,} \mathrm{Ti,} \mathrm{V,} \mathrm{Cr,} \mathrm{Nb,} \mathrm{Ba,} \mathrm{Hf,} \mathrm{Th,} \mathrm{U)} \mathrm{and} 0.008 \mathrm{~s} \mathrm{(Sr,} \mathrm{Y,}$ $\mathrm{Zr}, \mathrm{Ta}, \mathrm{Pb}, \mathrm{REEs})$. The total sweep time was 0.297 s. Postacquisition processing was performed using the software Iolite (Hellstrom et al., 2008; Paton et al., 2011; Woodhead et al., 2007), with data reduction and image processing procedures following those outlined by Raimondo et al. (2017) and Hyppolito et al. (2018).

\section{5 | PETROGRAPHY AND MAJOR ELEMENT CHEMISTRY}

The schematic structure of a jadeitite body is shown in Figure 3c. A summary of studied samples is given in Table 1 and the paragenetic sequence for jadeitites and amphibole-phlogopite lithologies is provided in Figure 4. Additional optical microscopy pictures are provided in 

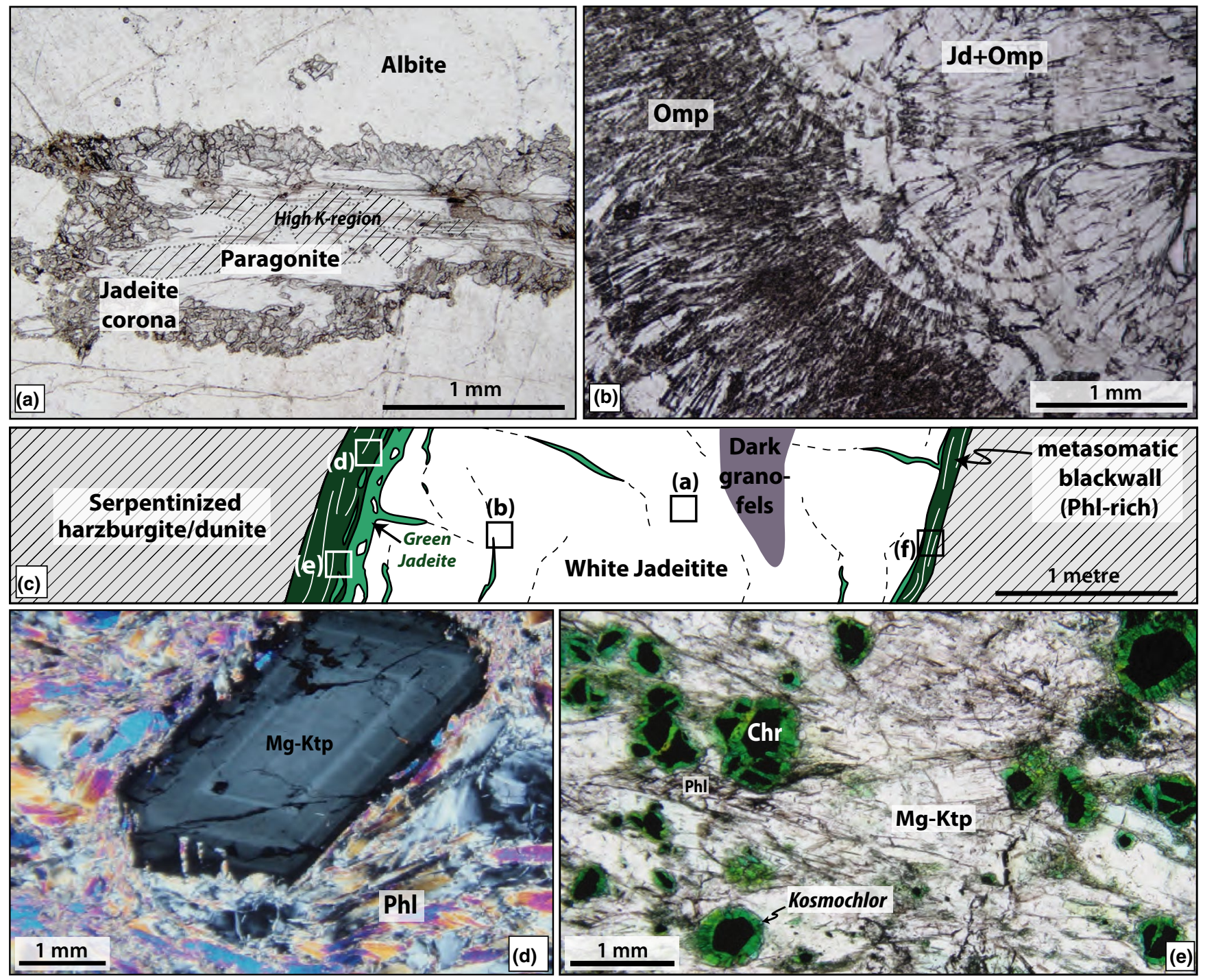

F I G URE 3 (a) Optical microscope image showing a paragonite crystal from sample PU3 rimmed by jadeite (Jd97) at the contact with large albite crystals. High-K regions in the paragonite core are also shown (see detailed X-ray maps in Figure S2g). (b) Microscopic view of a typical vein-filling habit where jadeite and fibrous omphacite co-exist (sample UR03b). (c) Sketch summarizing the structural relationships between the different parts of the jadeitite body and the host serpentinite. (d) Cross-polarized optical microscope image showing a large oscillatory Mgkatophorite crystal growing in a phlogopite schist (PU4). (e) Representative microscopic view of the contact between the serpentinite and the jadeitite rim showing a Mg-katophorite and phlogopite-bearing foliation enclosing fractured chromium spinel crystals rimmed by kosmochlor

Figure S1. Representative mineral analyses are presented in Table 2.

\subsection{White jadeitite cores (PU3, PU5)}

The cores of the white jadeitite lenses locally contain substantial amounts of albite $\left(\mathrm{Ab}_{99}\right)$ that exhibit incomplete transformation to jadeite. In sample PU3, the albite-rich matrix contains several paragonite flakes (up to $0.5 \mathrm{~mm}$ in length) separated from the host albite by a corona of euhedral jadeite crystals (typically $\mathrm{Jd}_{92} \mathrm{Quad}_{8}$ in composition; Figure $3 \mathrm{a}$ ). These relict paragonite crystals are characterized by relatively high-K contents (up to 0.17 apfu; Table 2; Figure 3a; see detailed X-ray maps in Figure S2g). In the vicinity of the albite-rich matrix several epidote grains with an average $\mathrm{Fe}_{2} \mathrm{O}_{3}$ content of $\sim 7 \mathrm{wt} \%$ have been found. In some parts of the matrix, clinopyroxene is heterogeneously distributed and displays a striped zoning pattern comprising intercalations of jadeite-rich $\left(\mathrm{Jd}_{80} \mathrm{Quad}_{10} \mathrm{Aeg}_{10}\right)$ and omphacite-rich lamellae $\left(\mathrm{Jd}_{45} \mathrm{Quad}_{45} \mathrm{Aeg}_{10}\right.$; Figure 5a). These domains resemble exsolution patterns already reported in other high- $T$ jadeitite studies (e.g. Cardenas-Parraga et al., 2012). SEM-based surface estimates of these domains provide integrated chemical compositions ranging between 62 and 78 mol.\% of the jadeite molecule (Figure 6a). In other regions, a zoning pattern with sub-millimetre to millimetre-sized idiomorphic 


\begin{tabular}{|c|c|c|c|}
\hline Zone & $\begin{array}{l}\text { Samp. } \\
\#\end{array}$ & $\begin{array}{l}\text { Paragenesis (ordered by } \\
\text { abundance) }\end{array}$ & Texture \\
\hline \multirow[t]{2}{*}{ White jadeitite } & PU3 & $\begin{array}{l}\text { Jd, Omp, Amp, Phl+(Pg, } \\
\text { Ab, Ep) }\end{array}$ & $\begin{array}{l}\text { Static albite, coronitic jadeite } \\
\text { around paragonite }\end{array}$ \\
\hline & PU5 & $\begin{array}{l}\text { Jd, Omp, Phl, Amp, Cal, } \\
\text { Clc }\end{array}$ & $\begin{array}{l}\text { Dusty, brownish jadeite cores } \\
\text { rimmed by clear jadeite } \\
\text { rims. Sheared phlogopite } \\
\text { transecting white, static } \\
\text { jadeitite. Interstitial } \\
\text { phlogopite laths between } \\
\text { jadeitite crystals }\end{array}$ \\
\hline \multirow[t]{3}{*}{ Green fractures } & PU2 & Jd, Omp, Phl, Amp & $\begin{array}{l}\text { Static, omphacite-phlogopite } \\
\text { bearing veins }\end{array}$ \\
\hline & UR03b & Jd, Omp & $\begin{array}{l}\text { Fibrous, oscillatory veins } \\
\text { cutting through a white } \\
\text { jadeitite matrix }\end{array}$ \\
\hline & UR06 & Jd, Omp, Phl & Sheared phlogopite \\
\hline \multirow[t]{4}{*}{ Dark granofels } & PY3 & $\begin{array}{l}\text { Amp, Phl, Jd, Omp, Cal, } \\
\text { k-Fsp, Clc, Rt, Ttn, Ab }\end{array}$ & $\begin{array}{l}\text { Static large amphibole crystals } \\
\text { with interstitial, intergrown } \\
\text { phl-clc laths }\end{array}$ \\
\hline & PY4 & Amp, Phl, Chr & Marked foliation \\
\hline & PY6 & Amp, $\mathrm{Phl}, \mathrm{Chr}$ & $\begin{array}{l}\text { Slightly sheared amphiboles } \\
\text { with oscillatory pattern and } \\
\text { blue rims }\end{array}$ \\
\hline & UR08 & Amp, Cr-Omp, Chr & $\begin{array}{l}\text { Foliated, amphibole-rich } \\
\text { breccia }\end{array}$ \\
\hline \multirow[t]{3}{*}{ Phlogopite schist } & UR10 & Amp, Phl, Omp, Chr & $\begin{array}{l}\text { Marked phlogopite-bearing } \\
\text { foliation, wrapping } \\
\text { amphibole-rich clasts }\end{array}$ \\
\hline & PY14 & $\begin{array}{l}\text { Amp, Phl, Omp, Jd, Clc, } \\
\text { Chr }\end{array}$ & $\begin{array}{l}\text { Clasts of fractured amphiboles } \\
\text { floating in a phlogopite-rich } \\
\text { foliation }\end{array}$ \\
\hline & PU4 & Amp, Phl, Clc & $\begin{array}{l}\text { Marked foliation, oscillatory } \\
\text { amphibole crystals }\end{array}$ \\
\hline Serp. & UR09 & $\begin{array}{l}\text { Atg, Ol, Mag, Mgs, Clc } \\
\text { (after Chr) }\end{array}$ & $\begin{array}{l}\text { Static serpentinite, } \\
\text { mesh texture, late } \\
\text { carbonate+magnetite veins }\end{array}$ \\
\hline
\end{tabular}

TA B LE 1 Summary of studied samples mineralogy and main textural features jadeite cores rimmed by oscillatory or interstitial omphacite is commonly observed (see for example Figure 7). Clinochlore $\left(X_{\mathrm{Mg}}=0.95\right)$ inclusions were observed in jadeite cores. Rare ribbons of amphiboles ranging in composition between a pargasitic-edenitic amphibole and Mg-katophorite randomly occur in the matrix $\left(\mathrm{Na}^{\mathrm{A}}=0.86-0.96\right.$ and $\mathrm{Na}^{\mathrm{B}}=0.46-0.69$; Figure $6 \mathrm{~b}$ ). Chromian spinel inclusions have been observed inside amphibole but are apparently absent from the white jadeitite groundmass. Zircon crystals (typically hundreds of $\mu \mathrm{m}$ long) are also found in the matrix. Clinochlore-rich chlorite $\left(X_{\mathrm{Mg}}=0.92\right)$ and phlogopitic mica are found along some fractures. The jadeitite matrix is partly affected along cracks and along grain boundaries by an albitization event, as well as a stage of late Na-rich zeolite formation (likely analcime). Rare pargasitic amphiboles are found within texturally late fractures.

\subsection{Green fractures (PU2, UR03b, UR06)}

Omphacite (typically $\mathrm{Jd}_{43} \mathrm{Quad}_{51} \mathrm{Aeg}_{6}$ ) is observed along fractures across the white jadeitite domain, either (a) overgrowing previous fragments as epitaxial oscillatory-zoned crystals (Figure $5 b$ ) or (b) as fibre-like needles pointing towards the core of the veinlet (Figures $3 \mathrm{~b}$ and $5 \mathrm{a}$ ). The Mg chemical map shown in Figure 5c shows white jadeite (blue) sharply transected by oscillatory-zoned clinopyroxene ranging between a jadeite-rich (green) and an omphacite-rich (orange-red) composition. Within these Mg-rich veins omphacite with a dendritic or spherule-like habit is present (Figure 5d), locally overgrowing a previous jadeitite clast. Omphacite also occurs distributed in the white jadeite-rich matrix along jadeite crystals rims (Figure 7). A jadeitic clinopyroxene $\left(\mathrm{Jd}_{83} \mathrm{Quad}_{12} \mathrm{Aeg}_{5}\right)$ is also 
F I G URE 4 Table summarizing the mineral growth relations observed in jadeitites (black line) and dark granofels (grey line) for the three main stages identified in their paragenesis

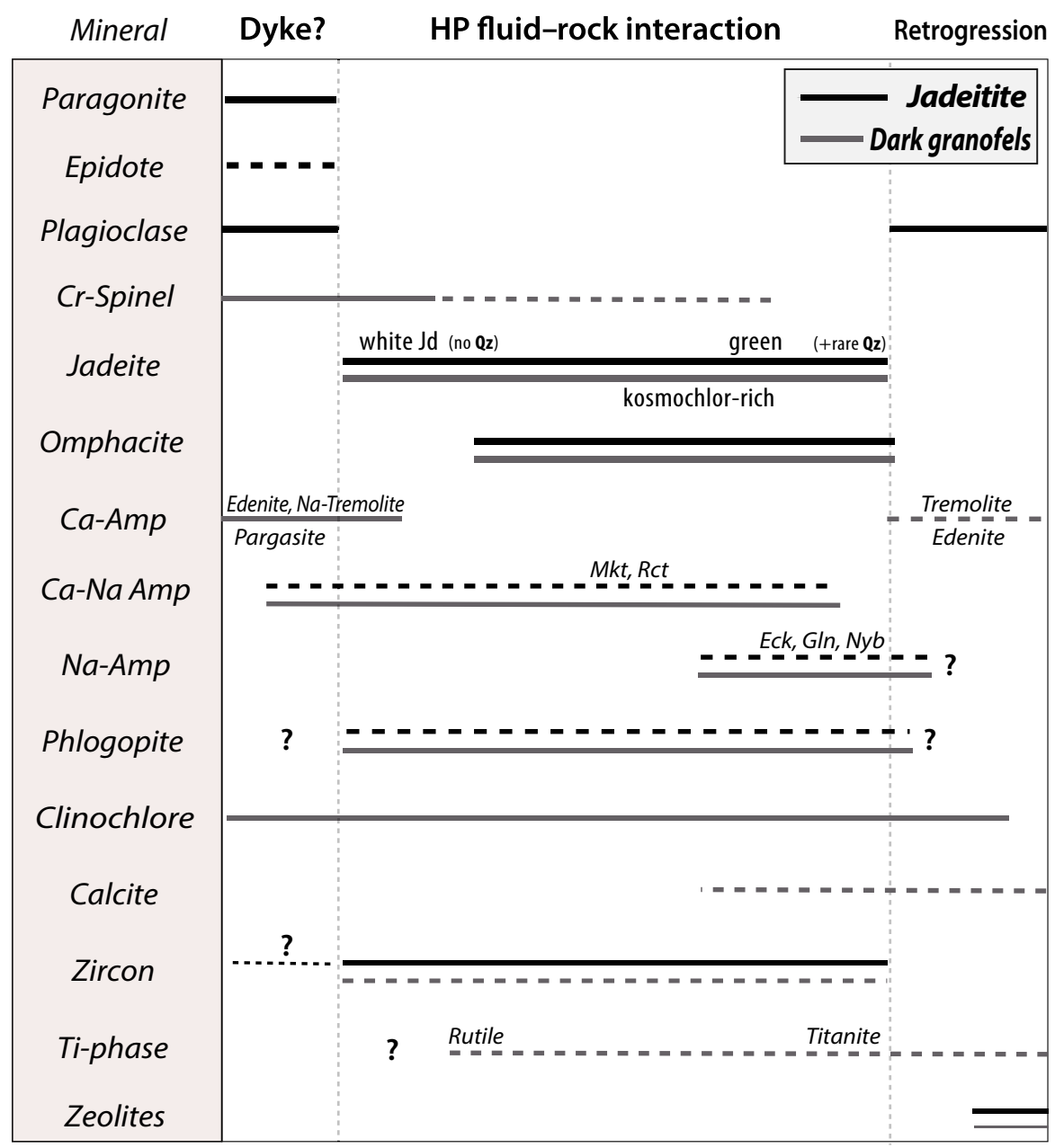

observed in the centre of omphacite-rich veins and fractures (locally in equilibrium with phlogopite and clinochlore) and some rare quartz crystals. The very last incremental clinopyroxene generation filling the vein core exhibits $20-60 \mu \mathrm{m}$ wide 'pockets' devoid of material or filled by a Ca-rich zeolite (Table S1 and Figures S1a and S2a). In some domains, phlogopite $\left(X_{\mathrm{Mg}}=0.95\right)$ is also observed as vein-filling material in equilibrium with $\mathrm{Cr}$-rich omphacite. In the vicinity of fractures, $\mathrm{Mg}$-katophorites from the matrix are rimmed by a $\mathrm{Na}$ and $\mathrm{Na}-\mathrm{Ca}$ amphiboles (Figure 6b; eckermannite and richterite; Table 2). Tiny, tens of $\mu \mathrm{m}$-sized zircon crystals are observed in the matrix as well as inside the crack (Figure 7). In a sheared domain, we identified at the SEM (EDS mode) rare $\mu$ m-sized crystals of As-Ni oxides that were too small to be accurately measured at the electron probe.

\section{3 | Dark granofels (PY3, PY4, PY6, UR08)}

The contact between the jadeitite and some amphibole-phlogopite granofels (referred as 'dark granofels' hereafter), rarely well exposed in the field, is very sharp in observed specimens. While we concur with Kuznetsov et al. (1986) that most dark granofels are found along the contact between the jadeitite body and the ultramafic host, some places exhibit dark granofels fragments apparently inside the white jadeitite (Figure 2c). In most cases, the pristine coarse-grained dark granofels texture is overprinted by a pervasive ductile imprint, well marked by phlogopite-rich bands and strongly deformed amphibole-rich bands. The most prevalent amphibole species are edenite and magnesio-katophorite, which display contiguous euhedral crystals (locally with oscillatory zoning), ranging in size from several hundred of $\mu \mathrm{m}$ up to several millimetres (Figure $3 \mathrm{~d}$ and Figure S2d). In this lithology, amphiboles rarely preserve their original core compositions ranging from pargasite to edenite (up to 0.7 wt $\% \mathrm{~K}_{2} \mathrm{O}$ and 0.4 wt $\% \mathrm{TiO}_{2}$; Table 2). Their $\mathrm{Ca}$ content generally decreases towards the rim (from $\sim 1.5$ apfu to 0.1- $0.5 \mathrm{apfu}$ ), whereas Na increases (from 1.0 1.5 apfu up to 2.0 2.9 apfu; Figure 6b). Most amphibole mantles show a magnesio-riebeckite (or richterite) composition. On the other hand, sodic amphiboles such as glaucophane $\left(X_{\mathrm{Mg}}=0.87\right)$, eckermannite or nyboïte (Table 2; Figure 6b) are commonly observed as thin overgrowths along rims as well as along cracks and fractures (Figure 5e). The common zoning trend of amphiboles points to the coeval interplay of substitutions such as $\mathrm{CaMg} \leftrightarrow \mathrm{NaAl}^{\mathrm{VI}}$ and $\mathrm{CaAl}^{\mathrm{IV}} \leftrightarrow \mathrm{SiNa}(\mathrm{M} 4)$ (e.g. Spear, 1993) which both contribute to the increase of $\mathrm{Na}^{\mathrm{B}}$ and the decrease of $\mathrm{Ca}$ as visible in Figure 6b. 


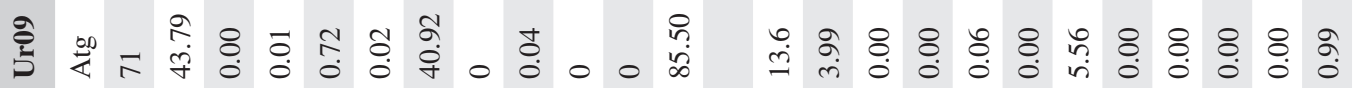

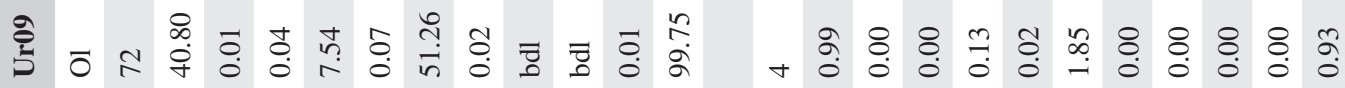

产

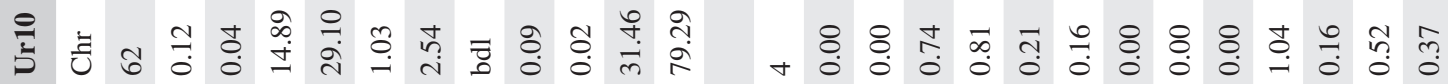

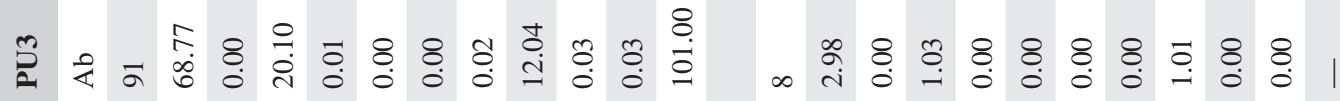

च च

蛋

司

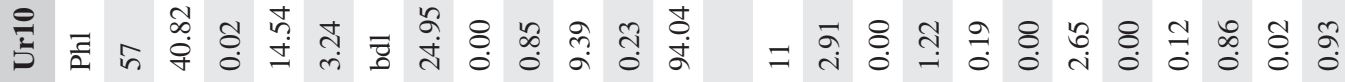

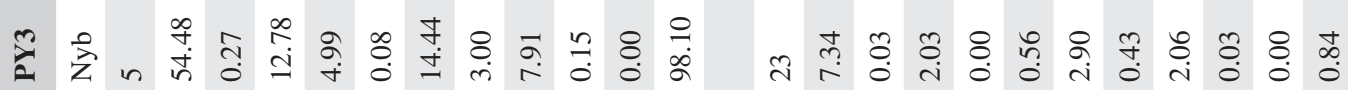

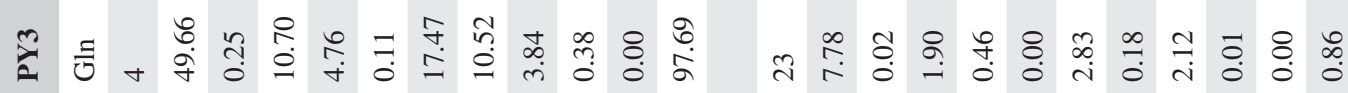

華

覀

壳

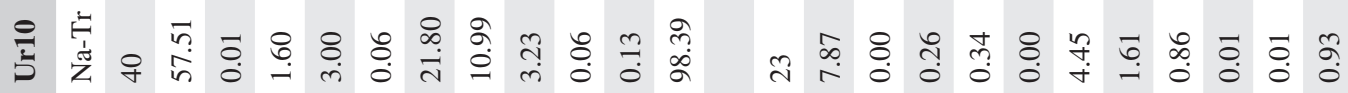

च ت

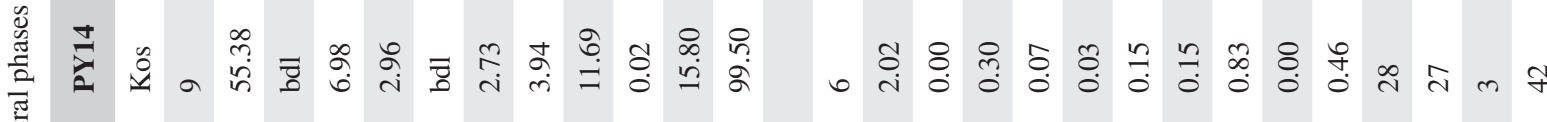

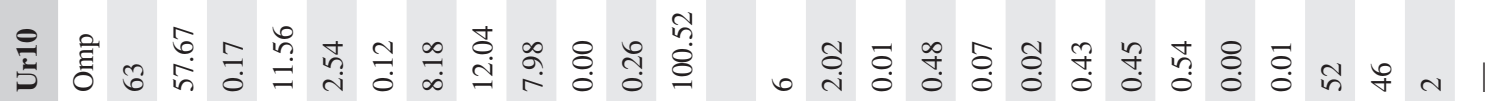

:

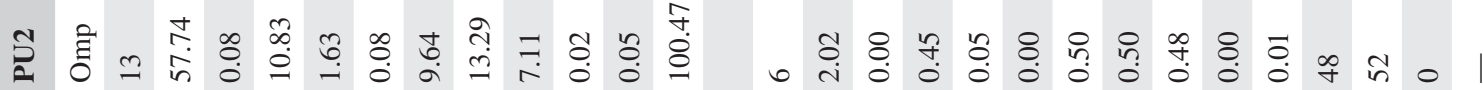

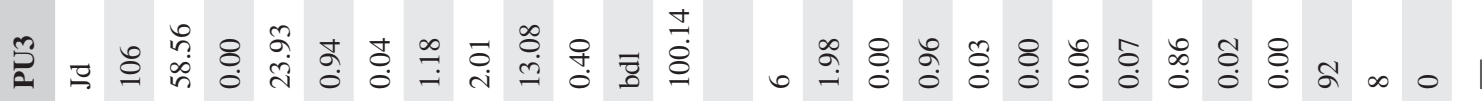

产

క

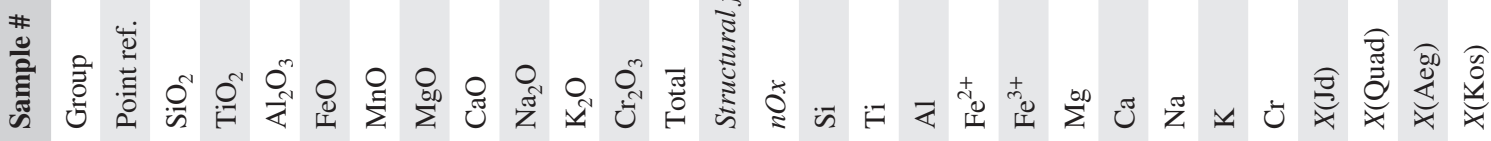



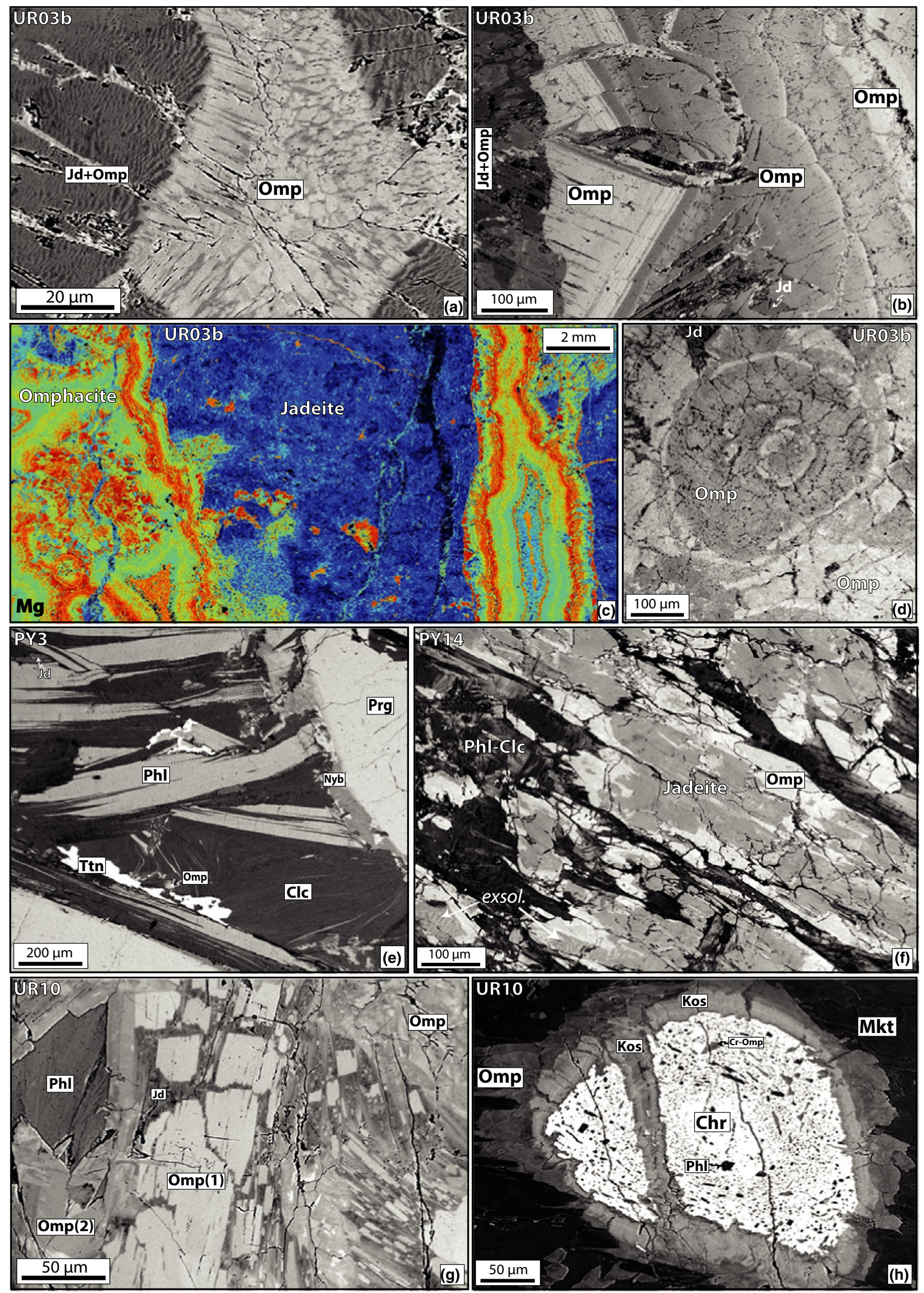
F I G U RE 5 Electron microscopy images showing various representative textures recognized among the studied samples. (a) Sample UR03b (white jadeitite) cross-cut by numerous omphacitic veins. The white matrix exhibits exsolution textures made by layers of jadeite-rich and omphaciterich clinopyroxene (BSE image). (b) Sharp fracture filled by several omphacite generations ranging from idiomorphic, oscillatory to dendritic habits towards the centre of the vein. (c) Mg X-ray map of sample UR03b showing how the white jadeitite (in blue here) partly re-equilibrates along cracks as omphacite. Note the presence of jadeitite clasts inside the omphacite veins. Warm colours are used for relatively high concentrations and cold colours for relatively low Mg concentrations (original data in counts, acquired at the SEM). (d) Spherulitic omphacite growing in the vein-filling material. Jadeitite is also present as late interstitial filling crystals within the spherulitic/dendritic domains that form in the veins (BSE image). (e) Late crack forming within a pargasite/edenite-bearing dark granofels. Note the rims of the very rare nyboïte in apparent textural equilibrium with clinochlore, phlogopite, titanite, omphacite and jadeite. (f) Jadeitite cores (that locally exhibit exsolution textures) partly dissolved and replaced by omphacite that grew in equilibrium with a fine intergrowth of phlogopite and clinochlore. (g) Phlogopite schist showing large idiomorphic omphacite grains fractured and healed by a jadeitic composition rimmed by another omphacitic clinopyroxene that grew in equilibrium with phlogopite. (h) High-contrast image showing a chromite grain partly replaced by a first generation of kosmochlor-rich clinopyroxene rimmed by a second generation of Cr-rich omphacite within a Mg-katophorite-rich matrix. Note the very high porosity (filled by $\mathrm{Cr}$-Omp and Phl) of the chromite that underlines the importance of dissolution and porosity formation in the mineral replacement process

(a)

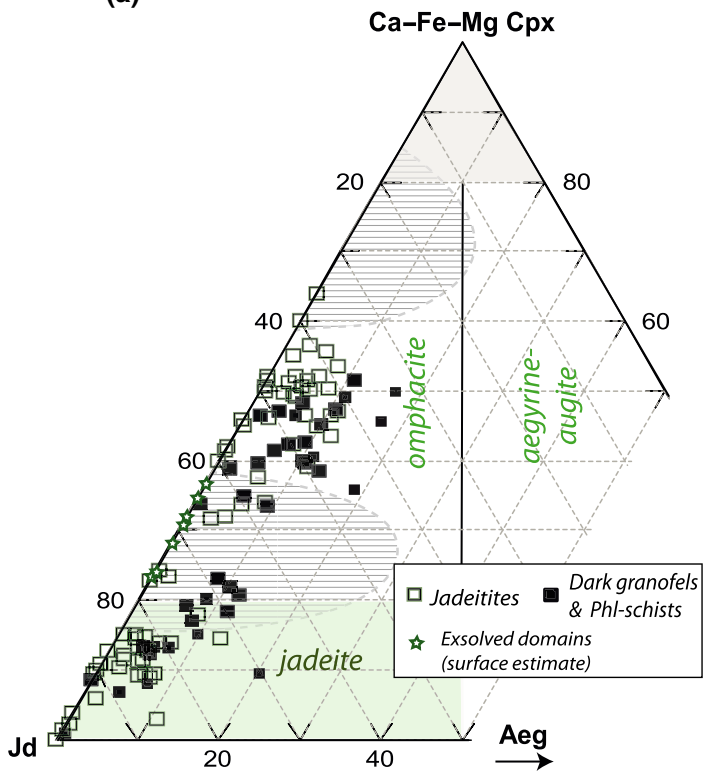

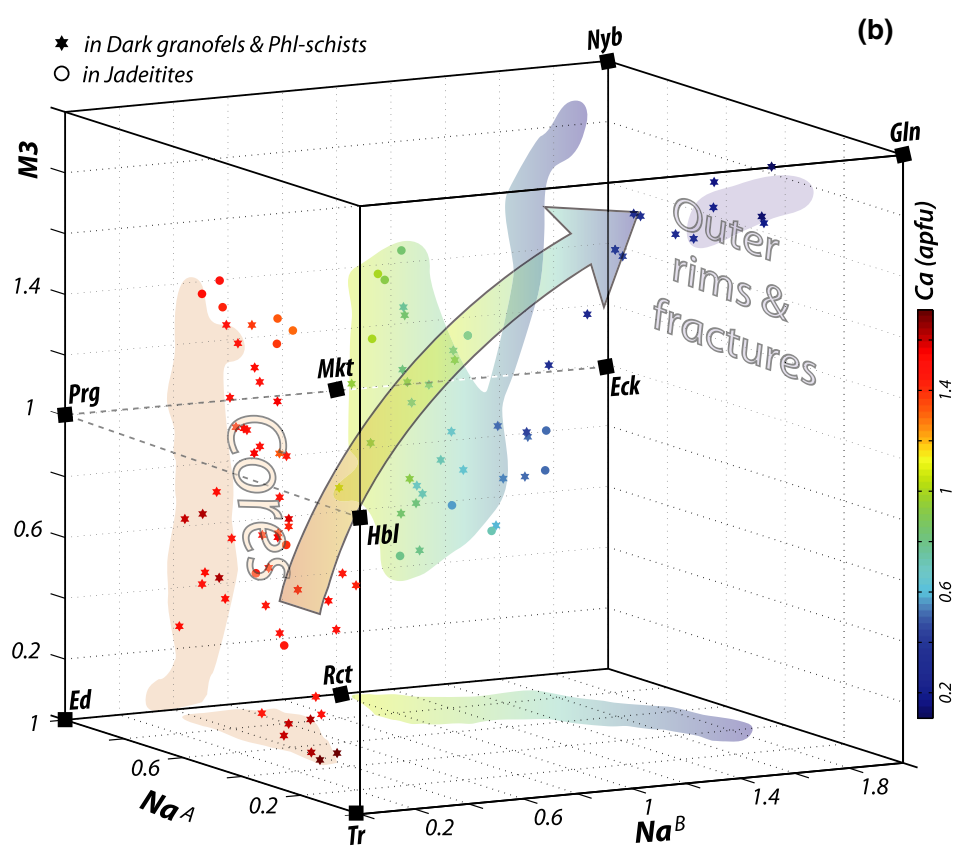

F I G U RE 6 (a) Ternary clinopyroxene plot (after Morimoto, 1989) showing the analysed compositions for jadeitites (white squares), dark granofels and phlogopite schists (black squares). Exsolved domains as shown in Figure 5 were measured using SEM surface estimates. They plot along the jadeite-diopside join. The striped area corresponds to the solvus relations calculated at $500^{\circ} \mathrm{C}$ by Green et al. (2007) in the hedenbergitefree system diopside-jadeite-acmite. (b) Three-dimensional plot of amphibole compositions (inspired from the classification of Hawthorne \& Oberti, 2007) using the $\mathrm{Na}$ contents in sites $\mathrm{A}$ and $\mathrm{B}$ together with the $\mathrm{M} 3$ content (where $\mathrm{M} 3=\mathrm{Al}^{3+}+\mathrm{Fe}^{3+}+\mathrm{Cr}^{3+}+\mathrm{Ti}^{4+}$ ). Shaded areas are projected on the faces of the cube to help reading mineral group compositions. Amphibole compositions (from jadeitites and from dark granofels and phlogopite schists) are coloured according to their calcium content (in atoms per formula unit). Crystal cores span a range between edenite, hornblende, Na-tremolite and pargasite. Mantles are mostly made by Mg-katophorite and richterite, while outer rims and fracture-filling amphiboles correspond to eckermannite, glaucophane or nyboïte. This figure illustrates that the starting amphiboles cores were already substantially enriched in $\mathrm{Na}$ (mostly in site A) and that the metasomatic replacement during cooling of the subduction gradient led to an increase in Na in the B-site (together with an increase in aluminum)

Interstitial domains between large amphibole crystals are filled by euhedral clinochlore flakes intergrown with minor phlogopitic mica. Amphibole cores and mantles commonly contain clinochlore inclusions as well as chromite crystals, embedded within amphibole mantles or as submillimetric porphyroclasts in the main foliation (Figure 3e). The largest chromite grains, that also contain inclusions of phlogopite, are commonly rimmed by fibrous kosmochlore crystals (up to $22 \mathrm{wt} \% \mathrm{Cr}_{2} \mathrm{O}_{3}$ ), a rare variety of $\mathrm{Cr}$-rich clinopyroxene (Shi et al., 2005). Some fractures are also filled by clinopyroxenes ranging from jadeite $\left(\mathrm{Jd}_{83} \mathrm{Quad}_{5} \mathrm{Aeg}_{12}\right)$ to omphacite $\left(\mathrm{Jd}_{34} \mathrm{Quad}_{49} \mathrm{Aeg}_{17}\right.$; Figure 6a). Bright, $\mu \mathrm{m}$-sized Ba-rich phases were occasionally identified by SEM (EDS mode) along grain boundaries and fractures, displaying a composition close to celsian or hyalophane $(\sim 2-\mathrm{w}] 3 \mathrm{wt} \% \mathrm{~K}_{2} \mathrm{O}$ and $20-\mathrm{w}] 25 \mathrm{wt} \% \mathrm{BaO}$ ). Fe-Ni sulphides (possibly pentlandite) 

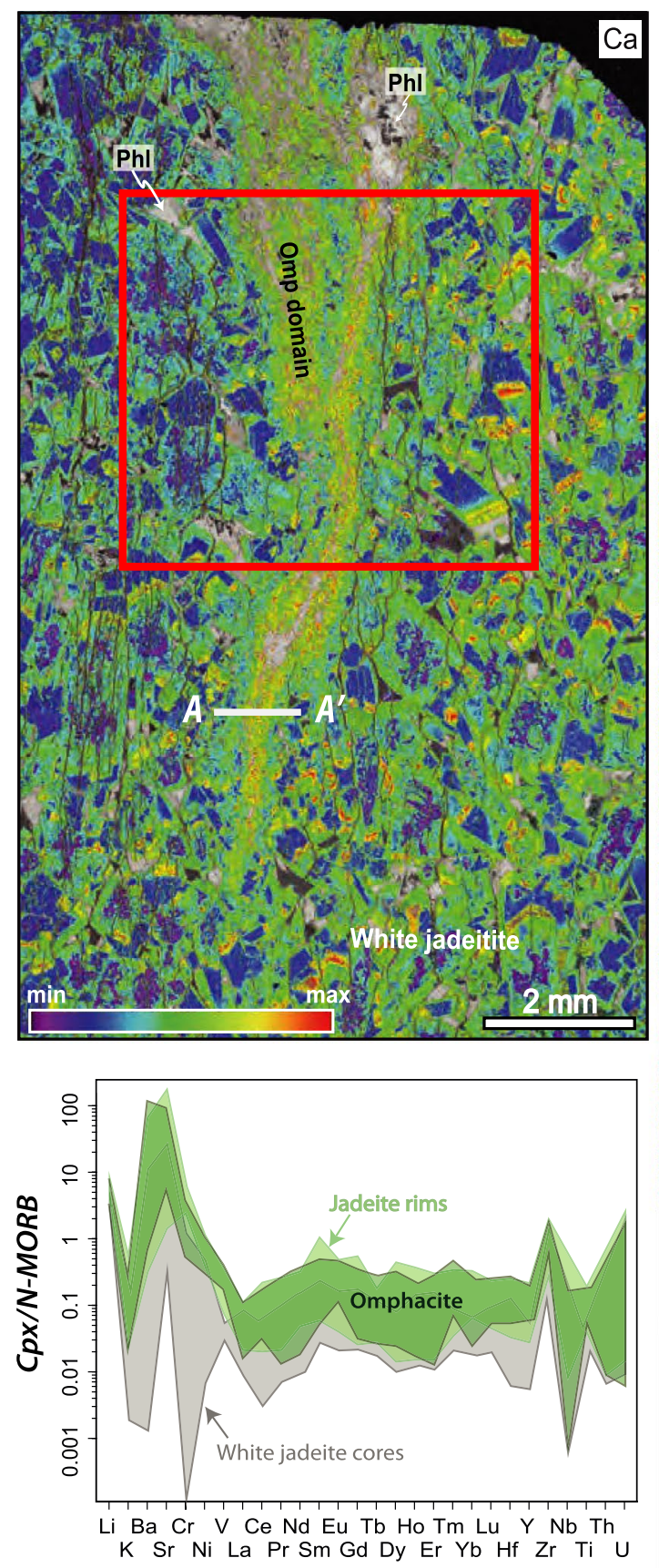

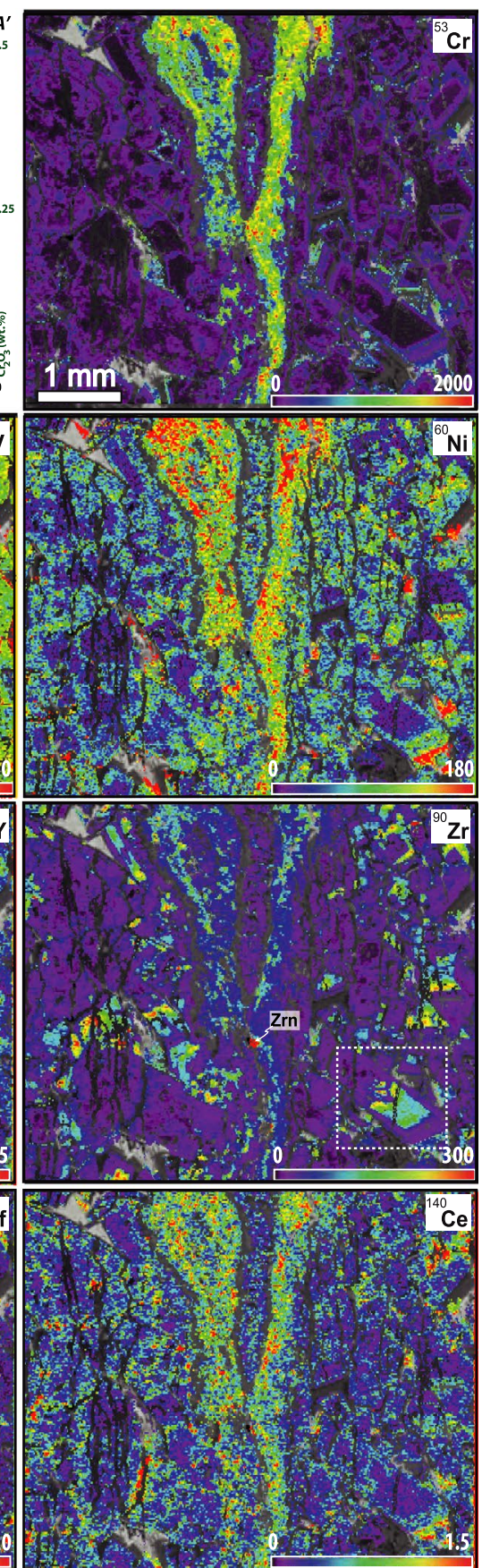

F I G U RE 7 Chemical data for a green omphacitic vein cross-cutting a white jadeitite groundmass. Matrix white jadeitite exhibits idiomorphic shapes and oscillatory zoning patterns. The increase in omphacitic component is well marked along their rims (see the Ca X-Ray map), as well as along the main crack. Also shown are trace element maps (in ppm) for a selected suite of elements (Cr, V, Ni, Y, Zr, Hf, Ce) in clinopyroxenes only (other phases such as phlogopite are displayed in the greyscale background). Representative analyses of the different texturally identified clinopyroxene generations were used to calculate and plot the N-MORB-normalized spider diagram, where a comparison of trace element contents of white jadeite cores, Ca-rich jadeite rims and omphacite is made

have also been identified by EDS. In the fractures, omphacite, jadeite, halite, clinochlore-rich chlorite, calcite, titanite or rutile are also found (Figure 5e). Some other cracks exhibit texturally late edenitic hornblende (in equilibrium with calcite and albite) post-dating the clinopyroxene-blue amphibole assemblage.

\subsection{Phlogopite schists (UR10, PY14, PU4)}

This melanocratic, schistose rock type is generally observed at the contact between jadeitite and serpentinites. It comprises alternating phlogopite-rich bands and amphibole-rich layers. Whereas phlogopite composition is 
rather homogeneous around $X_{\mathrm{Mg}}=0.9$ (Table 2), amphibole exhibits a wide range of compositions from (a) edenitic cores, (b) widespread Mg-katophorite or richterite needles and (c) thin eckermannite overgrowths and fracture fills (Figure 6b). Some samples also contain Na-rich tremolitic amphibole cores (with up to 3.2 wt $\% \mathrm{Na}_{2} \mathrm{O}$; Figure 6b; Table 2; $\mathrm{Na}^{\mathrm{A}}=0.47$ apfu and $\mathrm{Na}^{\mathrm{B}}=0.39 \mathrm{apfu}$ ), a composition rarely reported, for instance in xenoliths originating from the lithospheric mantle or in metasomatized palaeo-mantle wedge samples (e.g. Arai et al., 2019; Ishizuka, 1980). Eckermannite grows within $\mathrm{Mg}$ katophorite fractures in textural equilibrium with omphacite (from $\mathrm{Jd}_{42}$ Quad $_{46} \mathrm{Aeg}_{12}$ to $\mathrm{Jd}_{55}$ Quad $_{31} \mathrm{Aeg}_{14}$; Figure 6b; see also Figure S2e). Locally, hundreds of $\mu \mathrm{m}$-long needles of complexly zoned clinopyroxene (from $\mathrm{Jd}_{76} \mathrm{Quad}_{13} \mathrm{Aeg}_{11}$ to $\mathrm{Jd}_{42} \mathrm{Quad}_{47} \mathrm{Aeg}_{11}$ ) develop in the matrix together with phlogopite and amphibole (Figure 5f,g and Figure S2c). Some clinopyroxene aggregates define quadrangular shapes with distinct fabric and mineralogical composition (Figure S2f) pointing to pseudomorphic replacement of a former jadeiterich clinopyroxene crystal. Chromite $(\# \mathrm{Cr}=0.8-0.9$ with $\# \mathrm{Cr}=\mathrm{Cr} / \mathrm{Cr}+\mathrm{Al}+\mathrm{Fe}^{3+}$ ), which locally exhibits a texture suggesting dissolution-driven porosity formation (Putnis, 2009; Figure 5h), contains crystals of Cr-rich omphacite, phlogopite and is rimmed firstly by a layer of kosmochlore-rich clinopyroxene (10-15 wt $\% \mathrm{Cr}_{2} \mathrm{O}_{3}$ ) and secondly by a layer of $\mathrm{Cr}$-rich omphacite (1-3 wt $\mathrm{Cr}_{2} \mathrm{O}_{3}$ ). This aggregate has been sheared within a foliated $\mathrm{Mg}$-katophorite matrix (Figure 5h), together with phlogopite and rare clinochlore-rich chlorite. In rare places, a late edenitic composition overgrows Mg-katophorite margins.

\section{5 | Serpentinite (UR09)}

The serpentinitic schists wrapping jadeitite lenses mostly comprise antigorite $\left(X_{\mathrm{Mg}}=0.99 ; \mathrm{Al}_{2} \mathrm{O}_{3}=0.07 \mathrm{wt} \%\right)$ and magnetite that formed at the expense of olivine $\left(X_{\mathrm{Mg}}=0.92\right)$ and chromite. Magnesite $\left(\mathrm{Mgs}_{98}\right)$ occurs as vein-filling material (together with magnetite and calcite) as well as in the matrix. Tremolite, clinochlore (after chromium spinel) as well as uvarovite garnet have also been observed in an adjacent serpentinite sample.

\section{6 | Projection of bulk and mineral compositions}

The ACFN projection shown in Figure 8, calculated with the software Cspace (Torres-Roldan et al., 2000; see Garcia-Casco et al., 2013 for construction details), has been constructed to visualize the distribution of mineral compositions (points) with respect to whole-rock estimates (squares). Bulk-rock compositions used in this figure are given in Table S1. The spread of clinopyroxene analyses along the omphacite solid solution reflects the importance of the jadeite substitution $\mathrm{CaMg} \leftrightarrow \mathrm{NaAl}^{\mathrm{VI}}$ between diopside $\mathrm{CaMgSi}_{2} \mathrm{O}_{6}$ and jadeite $\mathrm{NaAlSi}_{2} \mathrm{O}_{6}$ end-members. The average of the whole-rock jadeitite compositions for the Pus'yerka locality (data from Meng et al., 2016) plots almost along the Jd-Di joint. The white jadeite-rich part of sample PU2 also exhibits a composition close to this average value. A composition has been estimated (by SEM-based surface methods) for a region of sample PU3 that contains the albite-paragonite association (inferred former trondhjemite, see discussion below) and has been only marginally affected by pervasive jadeitization.

Two surface composition estimates have been obtained for sample PY14 with a clinopyroxene-rich layer that plots closer to the jadeite tie-line and an amphibole-rich part of the thin section that plots within the cluster of amphibole probe analyses (Figure 8). Most amphibole compositions lie on a plane (not visible with the chosen angle of the projection) defined by nyboïte, tschermakite, tremolite-actinolite and richterite. Samples PY3 and PY6, which are both dark granofels, are localized in the middle of the amphibole data cluster. Phlogopite and clinochlore mineral data have also been projected in this figure to show their relative compositional homogeneity.

\section{MINOR AND TRACE ELEMENT MINERAL CHEMISTRY}

In order to visualize and decipher minor and trace element mobility, a sample of white jadeitite (PU2) cross-cut by a green, fine-grained omphacitic (phlogopite-bearing) domain has been mapped using X-ray probe and LA-ICP-MS raster mapping. In Figure 7, the coarse-grained, idiomorphic jadeitic cores are characterized by low $\mathrm{Ca}, \mathrm{Cr}, \mathrm{Ni}, \mathrm{V}, \mathrm{Y}$ and $\mathrm{Ce}$ (see Figure S3 for further element maps). Interestingly, these jadeitic cores exhibit relatively high $\mathrm{Zr}$ and $\mathrm{Hf}$ concentrations (up to $\sim 150$ and $\sim 20 \mathrm{ppm}$ respectively). The N-MORB normalized trace element spider diagram shows that the cores are relatively depleted for most trace elements compared to their (oscillatory) rims, which are enriched in $\mathrm{Cr}, \mathrm{V}, \mathrm{Ni}, \mathrm{Y}, \mathrm{Ce}$ as well as most fluid-mobile element(e.g. $\mathrm{K}, \mathrm{Ba}, \mathrm{Sr}$ ) and rare-earth element (REE). This overgrowth is locally depleted in both $\mathrm{Zr}$ and Hf compared to the cores (white-dotted square in Figure 7). The highest concentration of most minor and trace elements is found along clinopyroxene outer rims as well as along the omphacitic vein-like domain in the centre of the map. This enrichment is well marked on the Cr, V, Ni, Y, Zr, Hf and Ce maps (Figure 7; see also Figure S3). A small zircon crystal (possibly neoformed during vein formation) can be seen on the $\mathrm{Zr}$ and Hf maps. 
F I GURE 8 Projection of bulk-rock and mineral compositions in the $\mathrm{Na}_{2} \mathrm{O}-\mathrm{Al}_{2} \mathrm{O}_{3}$ $\mathrm{CaO}-(\mathrm{FeO}+\mathrm{MgO})$ system, projected from the phases and exchange vectors indicated in the figure. Representative end-members of the main solid solutions are indicated as black dots. $\mathrm{Fe}$ is treated as $\mathrm{FeO}_{\text {total }}$

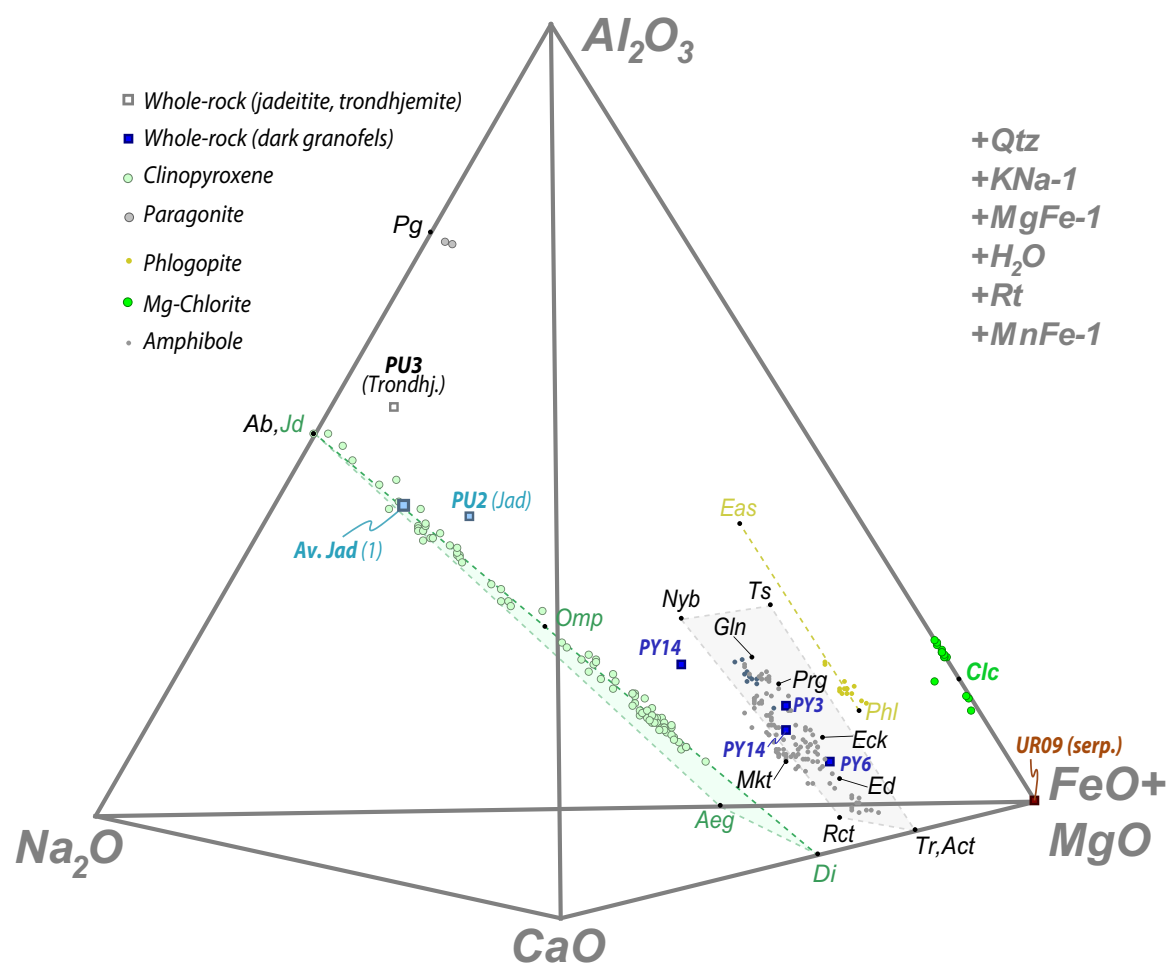

\section{7 | AGE CONSTRAINTS ON JADEITITE EVOLUTION}

\section{1 $\quad \mathrm{Rb}-\mathrm{Sr}$ results}

$\mathrm{Rb}-\mathrm{Sr}$ dating is a well-established geochronological method for dating the waning stages of dynamic recrystallization of mica in equilibrium with other, simultaneously recrystallizing Sr-bearing phases (Freeman et al., 1998; Inger \& Cliff, 1994), provided that no later thermal-diffusive or retrogressive reactive overprint occurred. Metamorphic crystallization of mica due to fluid-rock interaction, and mica precipitation from fluids in veins can be dated as well (Glodny et al., 2003). In the absence of retrogressive reactive fluids, thermal stability of the $\mathrm{Rb}-\mathrm{Sr}$ system of phlogopite is anticipated at temperatures up to $>600^{\circ} \mathrm{C}$ for geological timescales due to modally controlled closed system behaviour (Glodny et al., 2003, 2008; Kühn et al., 2000). The two samples selected for $\mathrm{Rb}-\mathrm{Sr}$ multi-mineral dating correspond to a phlogopite-jadeite-amphibole-bearing crack (UR06; Figure 2d) and a phlogopitejadeite hybrid schist (UR10; Figure 5g,h and Figure S2; see full analytical data set in Table S2). The isochron for sample UR10, calculated considering three phlogopitic mica (with slightly different densities and grain sizes), a blue-greenish amphibole and a Sr-rich feldspar (possibly celsian), yields an age of $394.5 \pm 3.4 \mathrm{Ma}$ (Figure 9) and is interpreted as dating cessation of ductile deformation. The isochron calculated for sample UR06, considering various phlogopite fractions (with slightly different magnetic properties) and two amphibole separates, exhibits a slightly older age of $399.9 \pm 3.5 \mathrm{Ma}$
(Figure 9) which is believed to date mineralization in the crack. Even though these two ages partly overlap, this age difference is kinematically compatible with textural observations showing that ductile shearing of mica-bearing domains post-dates crack formation.

\section{2 $\quad$ Ar-Ar results}

Four phlogopite-amphibole-bearing fragments from a phlogopite-bearing jadeitite (PU3), from two dark granofels (PY3, PY4) and from a phlogopite-amphibole schist (PU4) were analysed for Ar-Ar dating. The age spectra and isochron plots are shown in Table S3 and a summary of obtained ages given in Table 3. A striking feature of all these samples is the systematic presence of excess argon (see discussion below). Note that some amphiboles (PU3, PY3) contain a significant amount of ${ }^{38} \mathrm{Ar}$ derived from chlorine (Table S3), probably related to the presence of clinochlore or halite inclusions as noted above. All samples exhibit initial ${ }^{40} \mathrm{Ar} /{ }^{36} \mathrm{Ar}$ ratios between 400 and 900 in the isochron plots, much higher than the air value of 298.6. Recalculation of individual ages considering these ratios for initial argon yields rather homogeneous age spectra with plateau ages mostly comprised between 410 and $390 \mathrm{Ma}$. An example of this recalculation is shown in Figure 10. The uncorrected age spectrum displays apparent ages continuously decreasing from 532 to $424 \mathrm{Ma}$ for the last 10 heating steps representing more than $97 \%$ of the total ${ }^{39} \mathrm{Ar}$ released. On the isochron diagram, these steps plot on a straight line with an abscissa intercept age of $418 \pm 10 \mathrm{Ma}$ and 

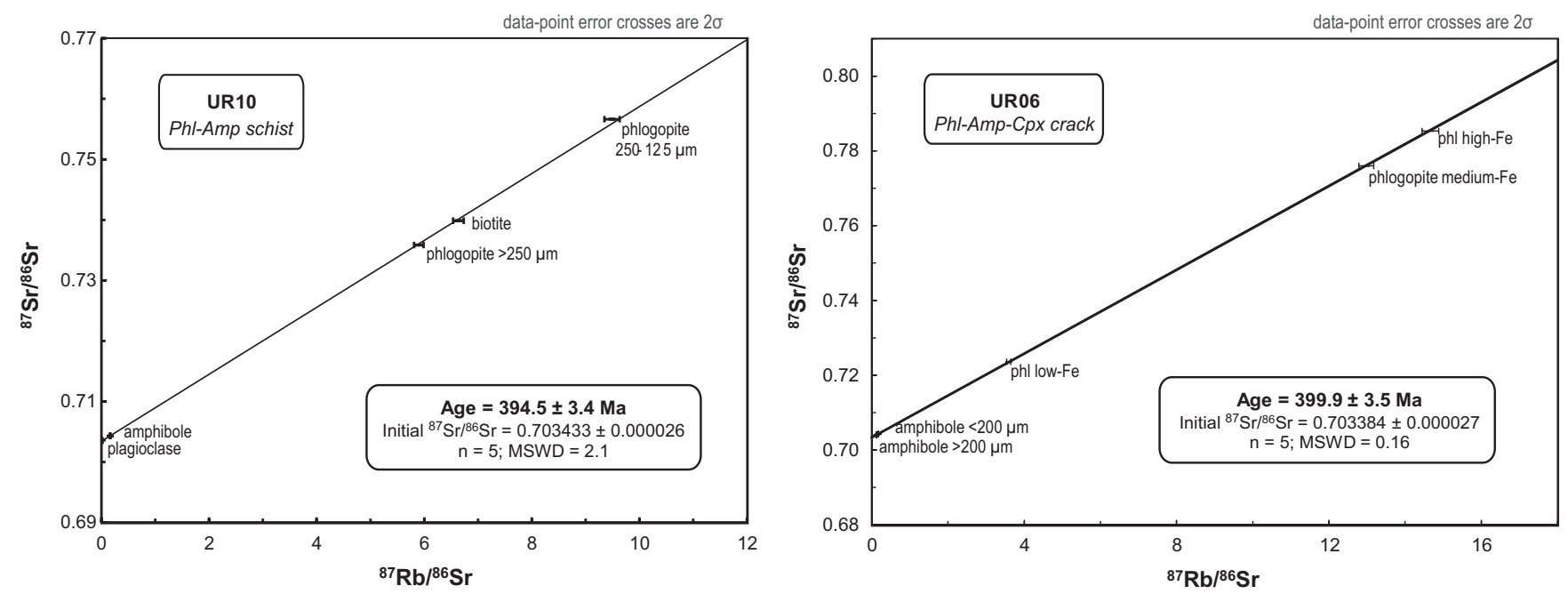

F I G U R E 9 Multi-mineral Rb-Sr isochrons for samples UR10 (left) and UR06 (right)

an ordinate intercept value for initial ${ }^{40} \mathrm{Ar} /{ }^{36} \mathrm{Ar}$ of $500 \pm 33$ well above the atmospheric value used to calculate the uncorrected age spectrum. The spectrum corrected by replacing the value of $298.6 \times 500$ in the calculation of apparent ages gives a plateau age of $415 \pm 5 \mathrm{Ma}$ for the same heating steps. The very first heating steps that represent loosely bound argon to the mica surface or lattice defects are not considered in this age re-evaluation.

A summary of the Ar-Ar age distribution, compared with $\mathrm{Rb}-\mathrm{Sr}$ ages from this study and other age data from the literature, is plotted in Figure 11. The oldest ages, 414.5 \pm 5.2 Ma (Figure 11), are obtained from amphibole (Ar-Ar) within amphibole-rich bands from the white jadeitite sample PU3. In this sample the phlogopitic mica has clearly undergone re-equilibration during a younger fluid-rock interaction event at $c .355 \mathrm{Ma}$. Amphiboles and phlogopites from the dark granofels PY3 exhibit (excess Ar-corrected) ages consistently in the range 410-w] $400 \mathrm{Ma}$. For the dark granofels PY4, two phlogopite single grains provide distinct plateau ages at $c$. $404 \mathrm{Ma}$ and c. $391 \mathrm{Ma}$, which could indicate partial argon loss for the younger grain. A similar disequilibrium pattern between amphibole and phlogopite is visible in the Phl-schist PU4, as the mica gives an older age of $c .403 \mathrm{Ma}$ whereas the amphibole has apparently re-equilibrated much later at c. $382 \mathrm{Ma}$.

\section{8 | DISCUSSION}

\section{1 | Petrological constraints on jadeitite evolution}

The Pus'yerka jadeitite locality in the Syum-Keu massif is among the best natural laboratories to understand how and when jadeitites crystallize in the mantle wedge. Our observations, in line with the previous studies by Kuznetzov et al. (1986) and Meng et al. (2011, 2016), highlight the gradual evolution of the white jadeitite into a hybrid, deep green amphibole-phlogopite mixture formed by metasomatic interaction along its rim at the contact between the jadeitite and the

T A B L E $3 \quad$ Summary of ${ }^{39} \mathrm{Ar}-{ }^{40} \mathrm{Ar}$ results

\begin{tabular}{|c|c|c|c|c|c|c|c|c|c|}
\hline Sample & Total age & $\begin{array}{l}\text { Pseudo- } \\
\text { plateau }\end{array}$ & ${ }^{39} \mathrm{Ar}$ & $\begin{array}{l}\text { Intercept } \\
\text { age }\end{array}$ & ${ }^{40} \mathrm{Ar} /{ }^{36} \mathrm{Ar}$ & MSWD & $\begin{array}{l}\text { Corrected } \\
\text { total age }\end{array}$ & $\begin{array}{l}\text { Corrected } \\
\text { plateau }\end{array}$ & $\%^{39} \mathrm{Ar}$ \\
\hline PU3 amphibole & $480.5 \pm 1.9$ & $472.0 \pm 9.9$ & 76.3 & $417.7 \pm 9.5$ & $500 \pm 33$ & 11.18 & $414.5 \pm 5.2$ & $414.5 \pm 5.2$ & 97.6 \\
\hline PU4 amphibole & $385.8 \pm 1.5$ & $387.2 \pm 3.7$ & 75.3 & $385.7 \pm 7.0$ & $353 \pm 171$ & 10.88 & $384.0 \pm 1.8$ & $382.3 \pm 2.8$ & 63.9 \\
\hline PU4 phlogopite 1 & $409.7 \pm 1.5$ & $411.3 \pm 2.0$ & 94.4 & $404.5 \pm 5.5$ & $385 \pm 63$ & 2.65 & $400.3 \pm 2.8$ & $402.9 \pm 2.6$ & 83.4 \\
\hline PY3 amphibole & $469.3 \pm 2.1$ & - & - & $408.5 \pm 11.1$ & $522 \pm 32$ & 4.85 & $398.0 \pm 7.9$ & $406.4 \pm 5.8$ & 81.2 \\
\hline PY3 phlogopite & $411.2 \pm 2.7$ & $410.6 \pm 1.5$ & 71.3 & $405.5 \pm 2.6$ & $411 \pm 41$ & 1.73 & $400.8 \pm 3.9$ & $404.1 \pm 4.0$ & 97.9 \\
\hline PY4 phlogopite 1 & $407.1 \pm 0.9$ & - & - & $391.1 \pm 1.4$ & $625 \pm 23$ & 4.05 & $387.7 \pm 1.7$ & $391.0 \pm 1.5$ & 91.9 \\
\hline PY4 phlogopite 2 & $430.4 \pm 1.4$ & - & - & $404.5 \pm 5.7$ & $510 \pm 42$ & 3.84 & $394.8 \pm 2.9$ & $403.4 \pm 2.6$ & 95.3 \\
\hline
\end{tabular}



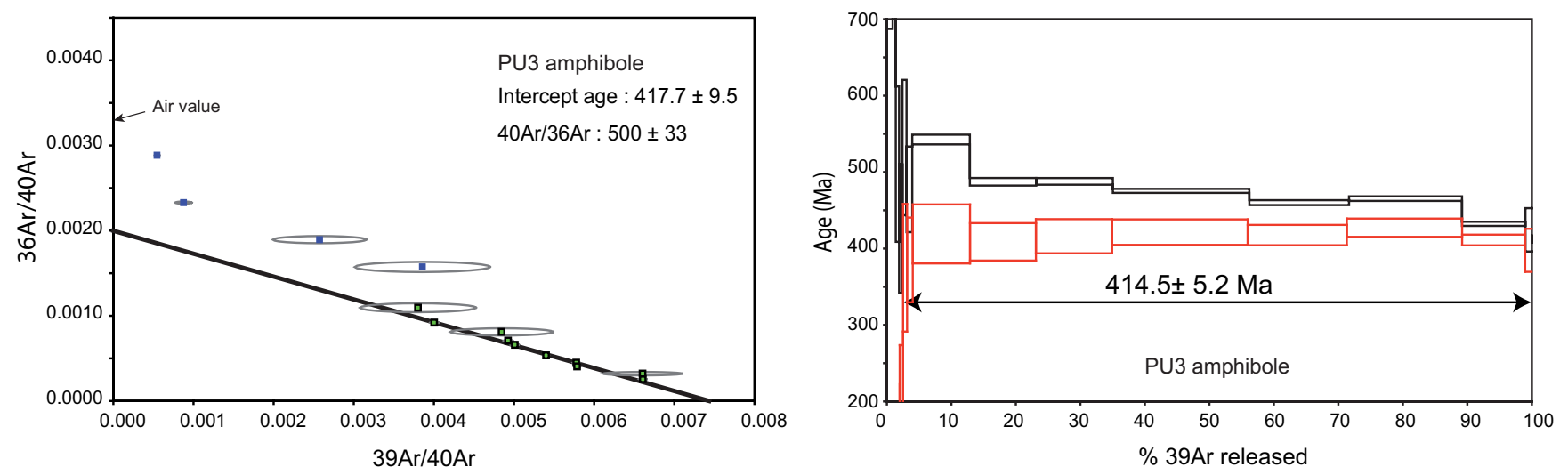

F I G URE 10 Isochron plot and uncorrected (in black) and corrected (in red) age spectra for a PU3 sample amphibole

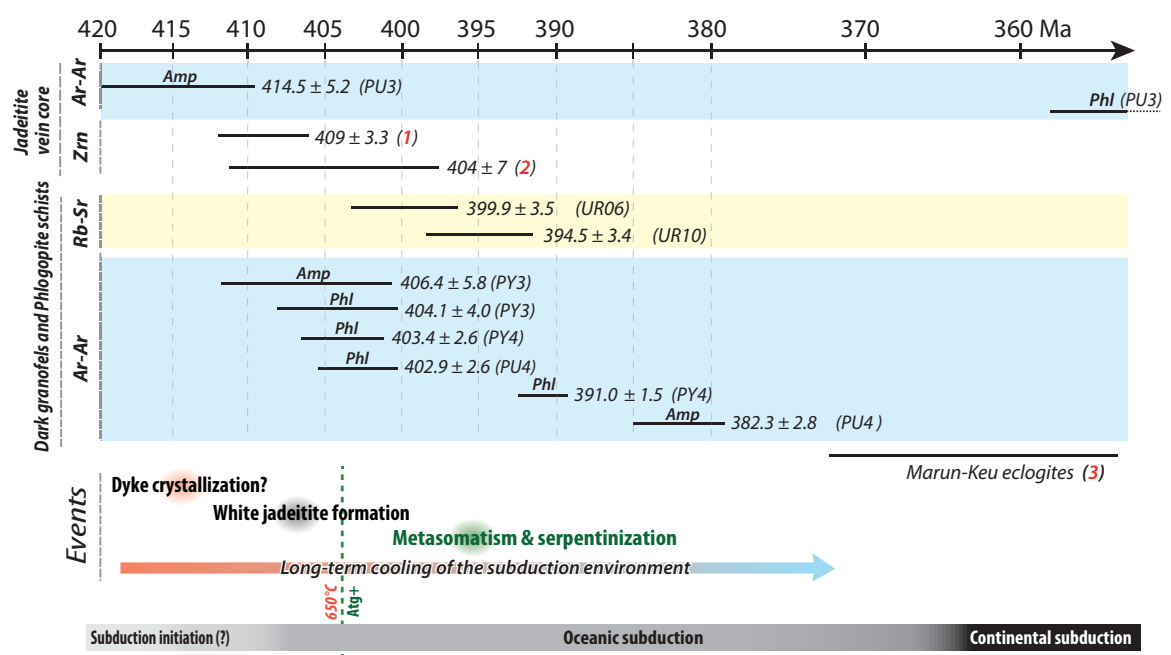

F I G U R E 11 Summary of ${ }^{39} \mathrm{Ar}-{ }^{40} \mathrm{Ar}$ ages obtained for four samples from jadeitite (PU3), dark granofels (PY3, PY4) and phlogopite schists (PU4). Detailed plateau age data (and applied corrections) are provided as a supplementary material. These ages are compared with $\mathrm{Rb}-\mathrm{Sr}$ ages from this study as well as previously obtained zircon U-Pb ages from (1) Konovalov and Sergeev (2015) and (2) Meng et al. (2011) for the Pus'yerka jadeitite body, and with the range of ages obtained by (3) Shatsky et al. (2000) and Glodny et al. (2003), Glodny et al. (2004) for the underlying Marun-Keu eclogites. These ages are related with the sequence of events described in the text

host, driven by the influx of externally derived fluids. The metasomatic assemblage, which has not been studied in detail at the Pus'yerka locality before, is known in other localities such as in the Jade Mine Tract, Myanmar (Nyunt et al., 2017; Shi et al., 2005) or in Guatemala (Harlow, 1994). A long-lasting, protracted petrological evolution is well marked by the amphibole zoning (Figure 6b), grading from $H T$ amphiboles (e.g. pargasitic hornblende, edenite) to the formation of narrow rims of sodic amphiboles (Figure 5e) such as nyboïte, eckermannite or glaucophane, which are considered as good markers of $H P-L T$ subduction zone gradients (Howe et al., 2018; Mével \& Kienast, 1986; Shi et al., 2012). This $H P-[\mathrm{w}] L T$ overprint, challenging to evaluate with accuracy in this open and high-variance chemical system, can be inferred from the widespread presence of exsolution textures in primary clinopyroxene crystals (Figure 5a,f): these textures have been interpreted as reflecting cooling below ca. $500^{\circ} \mathrm{C}$ (e.g. Cárdenas-Párraga et al., 2012; Garcia-Casco et al., 2009), a temperature which is also compatible with the formation of titanite, kosmochlor and glaucophane. The coeval presence of late jadeite and quartz in a vein sample constrains the pressure at a minimum value of $\sim 1.4 \mathrm{GPa}$ for a temperature of $500^{\circ} \mathrm{C}$ (Figure 12).

A key finding here is the report of a plagioclase-paragonite assemblage coexisting with edenite (or pargasite). This relict assemblage, commonly widely jadeitized (Figure 3a), is interpreted to derive from the emplacement and crystallization of a former felsic dyke (named 'plagioclasite' by Kuznetsov et al., 1986 without further chemical or petrographic details). Paragonite exhibits chemical characteristics (such as high K contents; see Figure S2g) that support an elevated crystallization temperature: Pus'yerka is the second 

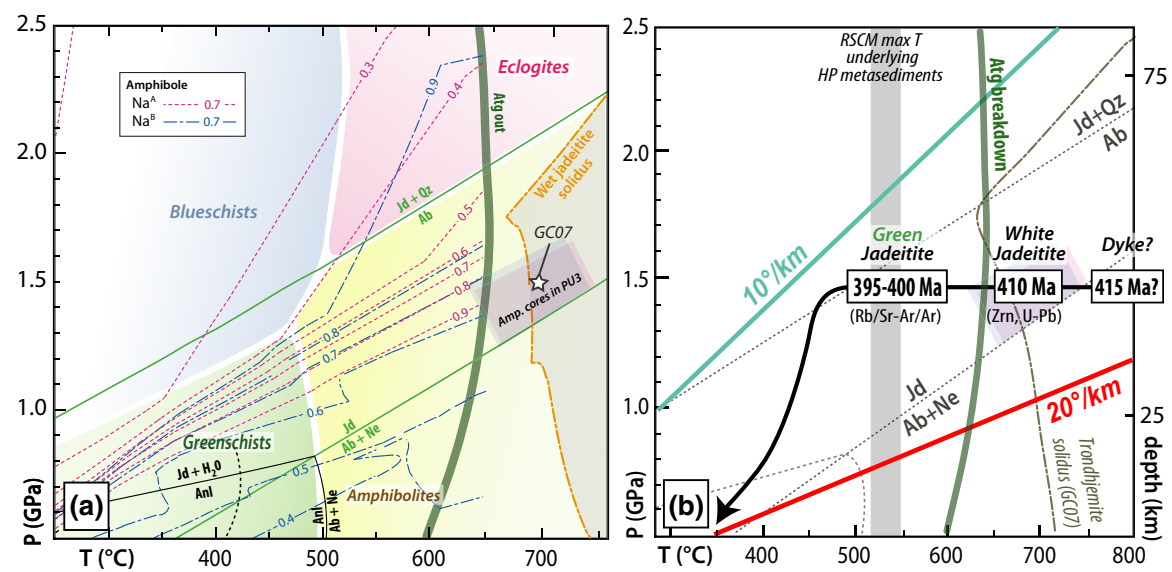

F I G URE 12 (a) Pressure-Temperature petrogenetic grid showing amphibole Na content (in sites A and B) as calculated for a jadeitite composition by Harlow et al. (2015) for the range $250-650^{\circ} \mathrm{C}$. Wet jadeitite solidus is also from this work. Amphiboles from the meta-trondhjemite PU3 have compositions that yield $P-T$ conditions inside the transparent pink/blue boxes. Constraints on the $T$ range for these boxes are provided in text. The $P-T$ estimates derived here are compatible with those proposed by Garcia-Casco $(2007,2008)$ for trondhjemites in the Cuban Sierra del Convento mélange (GC07). (b) Tentative sketch depicting the proposed $P-T$-time evolution of the Pus'yerka jadeitite body, combining petrological constraints together with new and existing age data. The trondhjemite solidus curve is from GC07. Temperature constraints on the underlying $H P$ metasedimentary rocks have been obtained by Raman Spectroscopy of Organic Matter (RSCM; Angiboust et al., in prep.)

locality after Sierra del Convento (Cuba) where a case of likely magmatic paragonite is reported (see also GarciaCasco, 2007; Garcia-Casco et al., 2008). Although the original dyke composition is impossible to determine with accuracy (due to some minor jadeitization imprint involving possible dissolution/reaction of original magmatic quartz), sample PU3 exhibits in the paragonite-bearing region a local composition that ranges between an Al-rich albitite and a peraluminous, Ca-poor trondhjemite (Table S1; see its projected composition in Figure 8). The (rare) calcic amphiboles that coevally grew within the PU3 matrix may help constrain the $P-T$ conditions of crystallization of this dyke. Approximate amphibole-forming $P-T$ conditions are reported in Figure 12 (grid modified from Harlow et al., 2015), extrapolating the calculated $\mathrm{Na}^{\mathrm{A}}$ and $\mathrm{Na}^{\mathrm{B}}$ contents at the entrance of the melt-bearing region: temperatures greater than $650^{\circ} \mathrm{C}$ (due to the presence of melting) and pressures in the range 1.4 w] $1.6 \mathrm{GPa}$ are proposed. These $P-T$ conditions are compatible with those obtained for the other example of paragonite-bearing, peraluminous meta-trondhjemite from the Sierra del Convento mélange $\left(1.5 \mathrm{GPa}, 700^{\circ} \mathrm{C}\right.$; Garcia-Casco, 2007). The presence of albite instead of jadeite in the original dyke also implies pressure conditions lower than $1.5 \mathrm{GPa}$ at temperatures $>700^{\circ} \mathrm{C}$, consistent with the local presence of epidote/(clino)zoisite. Therefore, and in the absence of further petrological indicators (e.g. lawsonite, phengite, garnet), we hypothesize that the pressure remained relatively constant during the entire cooling of the Pus'yerka jadeitite locality as depicted in Figure 12 (see Blanco-Quintero et al., 2011; Endo et al., 2015; Krebs et al., 2011; Lázaro et al., 2009, for other, comparable examples of long-term subduction cooling in Caribbean mélanges and the Sanbagawa belt respectively).

\section{2 | Age constraints on emplacement and alteration of the jadeitite-bearing dyke}

The replacement of a felsic dyke to enable the formation of jadeitite bodies is an idea that has been proposed by Bleeck (1908), Lacroix (1930) and Chhiber (1934) based on observations made on now-disappeared exposures in TawMaw (northern Myanmar). Similar observations mentioning albitite dykes jadeitized along their margins have been made in another jadeitite-bearing $H P$-w] $L T$ suture zone in the Itoigawa region (Japan) by Iwao (1953). Bleeck (1908), redrawn in Harlow et al., 2015) also mentions the presence of schistose amphibole-rich inclusions (such as in Figure 2c) within as well as along the margins of the jadeitite body, similar to our observations at Pus'yerka. Because the amphiboles in the dark granofels studied here have an edenitic-pargasitic composition similar to those found in the white jadeitite PU3 (meta-trondhjemite), it is proposed that these dark granofels crystallized slightly before the (magmatic) crystallization of the felsic dyke (see following section). Note that their relatively high $\mathrm{CaO}$ content (6-w] $10 \mathrm{wt} \%$ ) goes against direct diffusional chemical exchange along the jadeitite-peridotite boundary as a formation mechanism, as both jadeitite and peridotite have $\mathrm{CaO}$ contents lower than $1 \mathrm{wt} \%$ (see also a similar discussion in Coleman, 1961 and Mével \& Kienast, 1986; see a comparison of rock compositions plotted in Figure S4). 


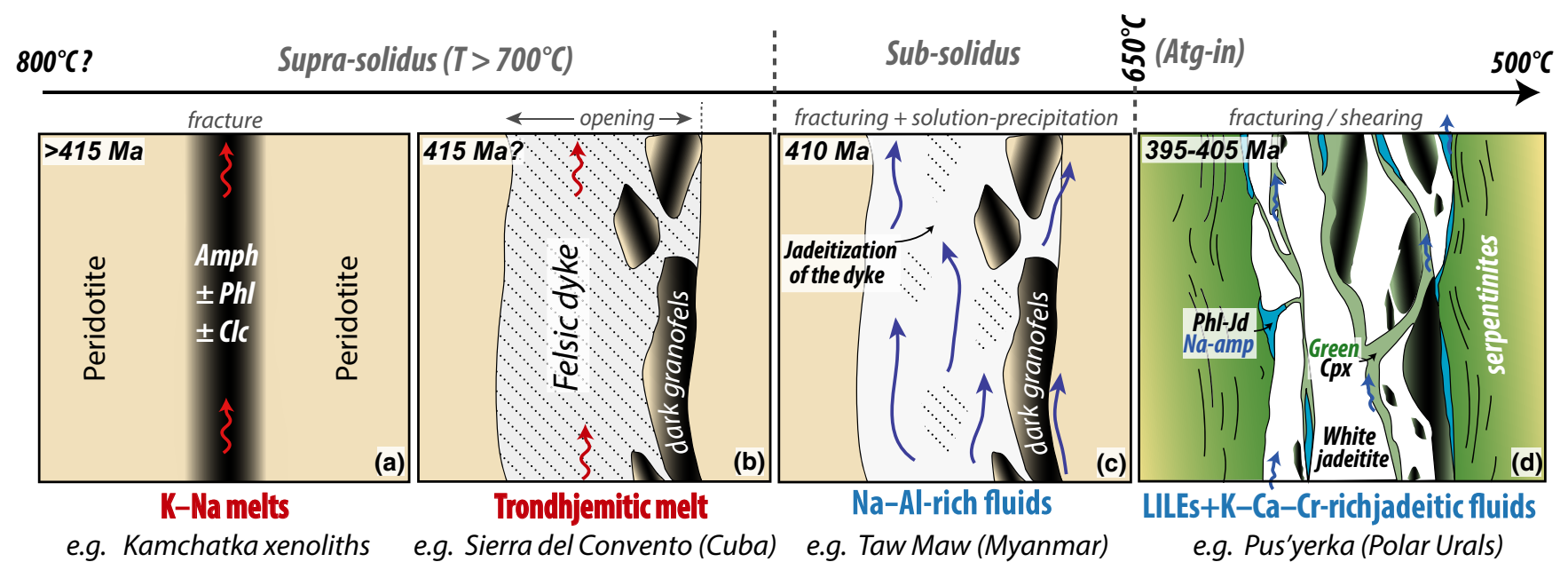

F I G URE 13 Schematic reconstruction of the evolution of the jadeitite body (not to scale). After initial fracturing of the mantle wedge (perhaps during subduction initiation), K-Na melts (red arrows) infiltrated a fracture zone, causing metasomatism of the host peridotite and leading to the crystallization of dark granofels. A natural analogue of this process can be observed in Kamchatka xenoliths (e.g. Kepezhinskas et al., 1995). Based on field relationships, we infer that the same network was re-opened upon a later melt infiltration event from which a trondhjemitic dyke (comprising "enclaves" of previously formed dark granofels) has crystallized. Similar trondhjemites are reported in Sierra del Convento, Cuba (García-Casco et al., 2008). During the isobaric cooling stage depicted in Figure 11, sub-solidus conditions were reached and fluxing of Na-Alrich fluids (blue arrows) derived from the dehydrating slab almost fully replaced (i.e. jadeitized) the previous paragonite-bearing trondhjemitic dyke. Such a wide, white jadeitite dyke resembles that described by Bleek (1908) in the TawMaw region (Myanmar). Cooling and fluid infiltration below the upper thermal stability of antigorite $\left(\sim 630^{\circ} \mathrm{C}\right)$ led to serpentinization of the host peridotite and the formation of phlogopite schists and green jadeitites along cracks, fractures and dyke edges, as observed presently in Pus'yerka locality. Further shearing and block-in-matrix mixing of such material will upon ongoing subduction dismember within a serpentinite mélange, as described for instance along the Motagua Fault Zone in Guatemala (e.g. Harlow, 1994)

Some inferences on the timing of the crystallization of this dyke can be made by combining existing and new petrochronological data. Whereas previously published zircon $\mathrm{U}-\mathrm{Pb}$ ages are in the range $412-\mathrm{w}] 397 \mathrm{Ma}$ for the white jadeitite (Konovalov \& Sergeev, 2015; Meng et al., 2011, 2016), we show here that amphiboles record a broad age range that overlaps with the oldest jadeitite zircon ages (c. $410 \mathrm{Ma}$ ) for the most pristine $\mathrm{Ab}-\mathrm{Pg}$ bearing jadeitite (PU3: 420-W]409 Ma; Figures 10 and 11). Based on field, petrographic and age relationships, we propose that the albite-paragonite-edenite assemblage formed coevally with the zircon crystals that were extracted from the white jadeitite and dated by Meng et al. (2011). In other words, it is proposed here that some of the oldest ages obtained by previous workers on the zircon crystals from this jadeitite (e.g. the points 9 and 17 from Meng et al., 2011) may reflect the timing of felsic dyke crystallization at $c .415 \mathrm{Ma}$ rather than jadeitization of the felsic body. This interpretation, in line with the findings from Fu et al. (2010), Yui et al. (2012) and Hertwig et al. (2016) highlighting the multiplicity of zircon-forming events in jadeitites, provides an interesting perspective on the paradox raised by Harlow et al. (2015), who pointed out that jadeitite zircon ages are in general substantially older than peak burial metamorphic ages for the crustal rocks associated with jadeitites in $H P-\mathrm{w}: L T$ serpentinized mélanges (see also Tsujimori \&
Harlow, 2012). A magmatic origin of the jadeitite zircon crystals dated by Meng et al. (2011) is also compatible with the $\varepsilon \mathrm{Hf}(\mathrm{t})$ (mostly in the range $5-10)$ and $\delta^{18} \mathrm{O}$ zircon isotopic values (5-wi]6 per mil) obtained in Meng et al. (2016). Additionally, the 5-[w] 10 Ma timespan proposed here between dyke crystallization and jadeitite precipitation (see Figure 13) is similar to the $c .5 \mathrm{Ma}$ window inferred for Sierra del Convento between the tonalitic-trondhjemitic samples (112.8 $\pm 1.1 \mathrm{Ma}$; Lazaro et al., 2009) and the P-type jadeitite ages (107.4 $\pm 0.5 \mathrm{Ma}$; Cardenas-Parraga et al., 2012; U-Pb SHRIMP zircon ages). This similarity thus supports the assumption of a common formation mechanism between Cuban and Russian jadeitites, which would both have formed after fluids evolved from hydrous trondhjemitic liquids that would have produced P-type jadeitites in Cuba and R-type jadeitites in the Urals (P- and $\mathrm{R}$-type jadeitites refer to fluid precipitate and metasomatic replacement, respectively, according to the classification defined in Tsujimori \& Harlow, 2012 and Harlow et al., 2015). The relatively large spread towards younger ages (c. $390 \mathrm{Ma}$; points 8 and 18 from Meng et al., 2011) would in our understanding either reflect the presence of dissolution-precipitation processes (e.g. Lei et al., 2016) and/or protracted Zrn crystallization over several Ma (e.g. Flores et al., 2013; Meng et al., 2016). The latter process is visible in the trace element maps (Figure 7) that clearly 
show $\mathrm{Zr}-\mathrm{Hf}$ enrichment and the presence of a small zircon crystal formed along a green, omphacite-rich crack cutting across the white matrix. Note that Vakhrusheva and Ivanov (2018) recently obtained a $398 \pm 3$ Ma zircon U-Pb age on a corundum-bearing plagioclasite from the Rai-Iz massif, above the MUT zone. Further investigations should determine whether these plagioclasites can be viewed as a non-jadeitized equivalent to the felsic dyke identified in the Syum-Keu massif Pus'yerka locality.

Phlogopite, which texturally comes in a secondary position in the studied samples, exhibits Ar-Ar ages in the range 408-W]390 Ma (Figure 10), in line with the UR06 Rb-Sr age $(c .400 \mathrm{Ma})$. Although some of these ages overlap with 'dyke' ages, they are typically younger. Since all dated samples are affected by partial or complete jadeitization, the 405-w] 390 Ma range is hence considered as the main peak of phlogopite formation. We interpret these $\mathrm{Ar}-\mathrm{Ar}$ and $\mathrm{Rb}-$ $\mathrm{Sr}$ ages as crystallization ages rather than cooling ages because (a) theoretical closure temperature for Ar retention in phlogopite according to experimental diffusion data would be above $500^{\circ} \mathrm{C}$ (considering phlogopite crystal size greater than $200 \mu \mathrm{m}$ and the $P-T$ path from Figure 12; see calculation details in Villa, 2010), (b) Ar-Ar ages for phlogopite are similar to those obtained here for amphiboles, which are known to have a closure temperature of $550 \pm 50^{\circ} \mathrm{C}$ (Dahl, 1996), (c) presence of excess/initial Ar in phlogopite and amphibole a priori precludes a setting of the $\mathrm{K}-\mathrm{Ar}$ isotopic clocks by temperature-related closure to diffusive Ar removal simply because the initial Ar has never been fully lost. Most important (d), however, is the fact that kinetic aspects of nuclide transport in a rock are critical for the interpretation of $\mathrm{Rb}-\mathrm{Sr}$ and $\mathrm{Ar}-\mathrm{Ar}$ age signatures. If intermineral and grain boundary related transport in a rock is virtually inhibited, radiogenic ${ }^{87} \mathrm{Sr}$ and ${ }^{40} \mathrm{Ar}$ will remain locked in place in the $\mathrm{Rb}$ - and K-bearing phases because there are no alternative reservoirs within reach where these nuclides could move to. Whereas rapid nuclide transport via the intergranular space is typically mediated by fluids (Villa, 2010), the absence of fluids leaves intermineral diffusion as the only process capable to reset isotopic clocks. In the absence of fluids, isotopic closure is modally controlled (see discussion in Glodny et al., 2003), essentially by $\mathrm{Sr}$, Ar concentrations and diffusivities in the modally dominant phases of a rock. In fluid-absent, modally closed systems phlogopite $\mathrm{Ar}-\mathrm{Ar}$ and $\mathrm{Rb}-\mathrm{Sr}$ systematics have been shown to remain stable at temperatures well above $600^{\circ} \mathrm{C}$ (Rb-Sr, Kühn et al., 2000) or even at mantle ambient temperatures of $800-\mathrm{w}] 1,200^{\circ} \mathrm{C}(\mathrm{Ar}-\mathrm{Ar}$, Hopp et al., 2008). In conclusion, the here studied amphibole and phlogopite fractions from unretrogressed rocks are likely to date their crystallization within their respective high- $P$, high- $T$ assemblages.

Later deformation-assisted recrystallization may have caused partial or complete resetting of some phlogopite and amphibole ages, explaining the $\mathrm{Rb}-\mathrm{Sr}$ and $\mathrm{Ar}-\mathrm{Ar}$ ages in the range 395-380 Ma (and up to $c$. $355 \mathrm{Ma}$ in sample PU3; Figure 11). It is worth noting that sample UR06 contains abundant greenish, Cr-bearing sodic clinopyroxenes that grew at c. $400 \mathrm{Ma}$ (Figure 9) in equilibrium with phlogopite in a crack post-dating the white jadeitite (Figure 2d). Assuming that the $\mathrm{Cr}$ enrichment of clinopyroxene relates to the incipient serpentinization of the host (e.g. Tsujimori et al., 2005) and given the previously mentioned constraints on the jadeitite host age, it is proposed here that the down- $T$ crossing of the antigorite-in reaction (which occurs in the $630-650^{\circ} \mathrm{C}$ range in such a setting; e.g. Padron-Navarta et al., 2013; Wunder \& Schreyer, 1997) has been most likely achieved in the 405-w:400 Ma time window, contemporaneously with the bulk of the phlogopite precipitation (Figures 11 and 12).

\section{3 | Replacement processes and incoming fluid composition evolution}

The mineral formation sequence described in this study can help to constrain the evolution of fluid chemistry over a $c$. $30 \mathrm{Ma}$ period. It is widely accepted that fluids causing the formation of jadeitites derive from metamorphic dehydration reactions within the downgoing lithosphere, and more precisely those released near the blueschist-to-eclogite transition (e.g. Harlow \& Sorensen, 2005; Schmidt \& Poli, 2014). At high pressure under sub-solidus conditions, fluids in a supercritical state are compositionally far from pure water and are known to contain a large concentration of solutes such as $\mathrm{SiO}_{2}, \mathrm{Al}_{2} \mathrm{O}_{3}$ and $\mathrm{Na}_{2} \mathrm{O}$ (alkali-aluminosilicate polymerization; e.g. Manning, 2004; see also Schneider \& Eggler, 1986). Elemental solubility is enhanced by the presence of salts such as $\mathrm{NaCl}$ in the fluid phase (Newton \& Manning, 2010). Jadeitites are known to precipitate from fluids with salt content close to seawater (Kawamoto et al., 2018). At temperatures higher than $\sim 630^{\circ} \mathrm{C}$ (in the $1.0-[\mathrm{w}] 1.5 \mathrm{GPa}$ range), the same aqueous fluids can evolve into a hydrous silicate liquid formed by a polymerized molecular network (Ni et al., 2017). Elements classically considered as insoluble (e.g. Ti, Zr, Hf) may under these conditions become mobile in subduction environments, even in a water-rich solution (e.g. Rubatto \& Hermann, 2003; Sorensen et al., 2010).

Under warm subduction gradients $\left(>15^{\circ} \mathrm{C} / \mathrm{km}\right)$, trondhjemitic melts can occur due to slab melting (Garcia-Casco et al., 2008; Lázaro et al., 2011; Lázaro \& Garcia-Casco, 2008; Rapp et al., 1991). Only few examples of felsic melts, interpreted as related to subduction initiation or derived from a slab-rupture event, are reported in peridotites from mantle wedges (e.g. Cluzel et al., 2006; Kepezhinskas et al., 1995; Shimizu et al., 2004). The projection shown in Figure 8 highlights how compositionally close (in terms of major elements) the inferred 'trondhjemite' (sample PU3) is from a 
jadeitite, suggesting that the evolution from supra-solidus to sub-solidus conditions occurred at a relatively constant melt/ fluid composition, most likely between $c .415$ and $c .410 \mathrm{Ma}$ (Figure 12). Note, however, that a trondhjemite recrystallizing at $H P$ would transform into a jadeite+quartz assemblage. It is thus likely that some silica removal (not visible in the chosen projection) occurred during fluid-rock interaction.

Even though the pristine structural relationships between the felsic dyke and the dark granofels blocks have been thoroughly overprinted during the long-lasting metamorphic and metasomatic evolution of the jadeitite body, one can postulate that these dark granofels formed slightly before trondhjemite crystallization (Figure 13). Indeed, experimental studies, together with mantle xenoliths investigations have demonstrated that the infiltration of alkali-rich fluids (or a hydrous K-Na-rich silicate melt) into a peridotite at $T>700^{\circ} \mathrm{C}$ can lead to the formation of a range of amphiboles (such as pargasite, Mg-katorophorite and Na-tremolite) similar to those reported in the studied dark granofels (e.g. Pirard \& Hermann, 2015; Safonov \& Butvina, 2016; Soret et al., 2016; Figure 6b). Amphibole crystallization from a fluid (or from a melt) is also indicated by its oscillatory pattern as shown on the $\mathrm{Cr}_{2} \mathrm{O}_{3} \mathrm{X}$-ray map provided in Figure S2d. The occurrence of clinochlore inclusions in amphibole cores constrains amphibole crystallization to less than $900^{\circ} \mathrm{C}$ (e.g. Fumagalli et al., 2014). This interpretation differs from Chen et al. (2018) for the Hkamti Jade Mine in Myanmar, where similar dark granofels are considered as a blackwall alteration formed by reaction of the jadeitite with the host serpentinites (see Table S1).

Subsequently, the original trondhjemitic dyke has been almost completely obliterated by a sub-solidus jadeitization event (Figure 13). Previous geochemical investigations have demonstrated that the fluid from which this jadeitite formed derived from a subducted oceanic slab with only a minor sedimentary component (Meng et al., 2016). The studied textures in the jadeitites reveal that fracturing and migration of a $\mathrm{Na}-\mathrm{Al}$-rich fluid along grain boundaries assisted the nearly complete replacement of the protolith dyke. The original slab-derived fluid, possibly initially saturated in silica, may have reacted with the peridotites before emplacement in order to decrease the chemical potential of $\mathrm{SiO}_{2}$ and trigger the crystallization of jadeite at the expense of albite. This metasomatic replacement process (as defined by Korzinskii, 1959) has been already identified in early, pioneering studies by Dobretsov and Ponomareva (1968) in the Voikar (Polar Urals) and Prebalkhash regions, as well as by Kuznetsov et al. (1986) in the Pus'yerka jadeitites of the Syum-Keu massif. The presence of idiomorphic jadeitic crystals, commonly invoked to discount the presence of a pre-jadeitite protolith (Harlow \& Sorensen, 2005), would in our view reflect the development of a very high fracture-controlled porosity and permeability, with voids maintained open due to near-lithostatic pore fluid pressures. Coupled dissolution-precipitation (e.g. Putnis \& John, 2010) also played a critical role in digesting the dyke remnants, enabling the growth of idiomorphic clinopyroxene or amphibole crystals (see also Lei et al., 2016 for similar conclusions based on the geochemical investigation of Myanmar jadeitites).

The dark granofels, comparatively less affected by pervasive recrystallization than the jadeitites, exhibit abundant evidence for brecciation and cataclasis, which also enhanced fluid flow within and around them (Figure 12). Given the $\mathrm{Cr}$ - and $\mathrm{Ca}$-poor nature of the white jadeite replacing the dyke, we infer here that the incoming metasomatic fluid did not trigger serpentinization of the host peridotite, likely because the replacement occurred at a temperature greater than $\sim 630^{\circ} \mathrm{C}$, the upper $\mathrm{T}$ stability limit of antigorite (e.g. Padron-Navarta et al., 2013; Wunder \& Schreyer, 1997). We thus infer that the white jadeitite formation event occurred in a rather narrow $T$ window above $\sim 630^{\circ} \mathrm{C}$ and below $\sim 700^{\circ} \mathrm{C}$, that is, the typical temperature where trondhjemite solidus is crossed for most chemical systems (experimentally and thermodynamically calculated data by Schmidt \& Poli, 2004 and Garcia-Casco, 2007; Figure 12).

With progressive isobaric cooling of the system, the infiltrating fluids caused extensive serpentinization of the peridotitic host (Figure 13), releasing $\mathrm{Ca}$ and $\mathrm{Mg}$ (mostly from the pyroxenes) as well as $\mathrm{Cr}$ (mostly from the chromium spinels and pyroxenes). The activity increase of these elements in the fluid phase is evidenced for instance by the scarce $(<1$ vol.\%) formation of Cr-bearing omphacite along jadeite rims or along cracks (Figure 5). Additionally, the formation of phlogopite crystals along fractures, voids as well as along grain boundaries in jadeitites (Figure 7) indicates a mixed crustal source with a substantial contribution from the subducting metasedimentary rocks (e.g. Harlow et al., 2016; Morishita et al., 2007). Metasedimentary-derived fluids would be enriched in $\mathrm{K}$ as well as in Ar, also released by the breakdown of K-bearing phases, thus explaining the elevated amounts of initial Ar measured in phlogopite and amphibole precipitated from the metasomatizing fluids (e.g. Menold et al., 2016). The LILE, Y, Zr, Hf and Ce enrichment of omphacite confirms that the texturally late clinopyroxenes also grew from fluids with a marked metasedimentary signature (Figure 7).

\subsection{Fate of fluids atop the subduction interface}

The incomplete transformation of the jadeite-bearing dyke, which leads to complex overprinting disequilibrium textures, provides an opportunity to document the nature of the fluids infiltrating the base of the mantle wedge shortly after an inferred subduction initiation event (e.g. Meng et al., 2011). 
The initially very high temperatures $\left(>800^{\circ} \mathrm{C}\right)$ caused by the transfer of heat from the lithospheric mantle most likely have generated a thermal environment approaching sub-arc conditions. The alkali-metasomatism recorded by the most pristine dark granofels would in this model represent the infiltration of early fluids (or alkali-rich melts) in a dry mantle, thus potentially shedding light on the structures and pathways that exist below arc volcanoes (usually sampled by xenoliths from arc lavas such as in Kamchatka; e.g. Kepezhinskas et al., 1995; see also Arai \& Ishimaru, 2008). Since field investigations did not show evidence for similar dyke structures outside the Pus'yerka jadeitite network area (Figure 2), we postulate that the pathways where the alkali-metasomatism occurred have been later re-used by some trondhjemitic melts, derived from the melting of the downgoing plate at $T>700^{\circ} \mathrm{C}$ (Figure 13). Importantly, our study shows that a precursor such as a felsic dyke is necessary to form large volumes of white jadeitite in a subduction zone environment (up to $300 \mathrm{~m}$ thick dykes in Myanmar; Bleeck, 1908). Note that this does not preclude the possibility that in other localities some minor-sized jadeitite bodies formed from fluids precipitating in hydrothermal vein systems in the serpentinized peridotites (P-type), as proposed by Harlow and Sorensen (2005), Tsujimori and Harlow (2012) and Harlow et al. (2015).

The later jadeitization and serpentinization events, which occurred at sub-solidus conditions between $\sim 700$ and $\sim 500^{\circ} \mathrm{C}$ (Figure 13), are due to the infiltration of Na-Al-rich fluids, again along the same trondhjemite-bearing 'dyke' structure. The dyke thus represented a persistent fluid pathway, enabling high- $P$ slab-derived fluids to enter the base of the mantle wedge and travel up-dip, $\sim 1 \mathrm{~km}$ above the palaeo-interface (Figure 1b). A relatively high fracture-controlled permeability must have been necessary to re-open previously healed structures. It is envisioned that high pore fluid pressures that prevail in plate interface environments fluctuated from near to supra-lithostatic values, enabling the multiple-stage fault reactivation documented by our observations (Figure 5c; e.g. Davies, 1999; Halpaap et al., 2019). We conclude that pre-existing structural discontinuities such as dykes or fracture networks, rather than pervasive fluid flux, play a key role for conducting voluminous fluid quantities upwards in the mantle wedge.

\section{5 | Witnessing the onset of subduction mélange formation}

The Pus'yerka locality in the Syum-Keu massif represents a unique natural laboratory to study the physical conditions at the base of the mantle wedge at $\sim 50 \mathrm{~km}$ depth, coupled with its evolution over c. $50 \mathrm{Ma}$ from subduction initiation until closure of the oceanic basin and arrival of the continental margin (Figure 11). It also yields critical new information on how the base of the mantle wedge behaves during secular cooling of the subduction environment at rates of $\sim 10^{\circ} \mathrm{C} /$ Ma. In most jadeitite-bearing localities worldwide, several tens of Ma of plate convergence and exhumation history led to pervasive hydration of the base of the mantle wedge (Blanco-Quintero, et al., 2011; Harlow et al., 2015 and references therein), channel flow dynamics, as well as the complete block-in-matrix disruption of former continuous structures such as fracture zones or early dykes (CárdenasPárraga et al., 2012; Garcia-Casco et al., 2009). Mélangetype suture zones are known to host a wide diversity of lithologies including metasedimentary rocks and eclogites (e.g. Flores et al., 2015; Tsujimori et al., 2007). Our study highlights the geometry and formation mechanisms of jadeitites, meta-trondhjemites and dark granofels that are occasionally reported in serpentinized mélanges (Garcia-Casco et al., 2008; Krebs et al., 2012; Shi et al., 2003). While it has been recently demonstrated that jadeitites form during subduction (and not during exhumation; Flores et al., 2013), it is likely that some of the biggest white jadeitites masses now preserved as blocks in serpentinized suture zones (e.g. Bleeck, 1908; Dobretsov \& Ponomareva, 1968; Kuznetsov et al., 1986) formed initially at relatively high- $T$ conditions (i.e. in the $500-$ wi $650^{\circ} \mathrm{C}$ range). Note that no talcschists nor hybrid schists as known in mélange localities (e.g. Spandler et al., 2008) are reported in the Polar Urals. Further investigations should investigate (a) if this absence is related to the chemistry of the overlying peridotite, (b) if hybrid schist/ talc schist associations are really representative of the nature of the subduction hangingwall and (c) if hybrid schist/talcschist associations have formed upon exhumation by mixing with accreted metasedimentary rocks in a serpentinized environment. Was the degree of serpentinitization in the Uralian palaeo-mantle wedge insufficient to develop channel flow dynamics? Was the oceanic subduction event too short-lived to enable development of a weak channel as expected, for instance, in a highly serpentinized forearc environment (e.g. Marianas wedge; Tamblyn et al., 2019)? Our observations support the idea that most present-day forearc mantles are relatively weakly hydrated (Abers et al., 2017) and that Marianas-type settings-where chaotic serpentinite mélanges are inferred-are the exception rather than the rule.

\section{9 | CONCLUSIONS}

A boudinaged, dyke-like structure from the Polar Urals, hosted by partly serpentinized peridotite, is formed by white jadeitite with the layers of amphibole-phlogopite granofels and phlogopite schists. We show that the jadeitite body initially formed by the infiltration of alkali-rich fluids/melts before $c .410 \mathrm{Ma}$, leading to the crystallization 
of edenite-rich dark granofels and paragonite-bearing trondhjemites. Later, below the wet trondhjemite solidus but above the antigorite stability field, a pervasive Na-rich aluminosilicate fluid nearly fully replaced the previous trondhjemite (as well as the amphibole-rich lithologies) and favoured the crystallization of a white jadeitite, possibly at c. $410 \mathrm{Ma}$. Lastly, isobaric cooling below $630^{\circ} \mathrm{C}$ (at $\sim 1.5 \mathrm{GPa}$ ) is marked by (a) the formation of antigorite schists at the contact between the jadeitite and the host peridotite, and (b) the crystallization of a Cr-rich omphacite together with phlogopite and various Na-rich amphiboles (glaucophane, nyboïte, eckermannite) along white jadeitite edges and cracks, as well as inside dark granofels. $\mathrm{Rb}-\mathrm{Sr}$ and $\mathrm{Ar}-\mathrm{Ar}$ dating indicate that this event occurred between c. 410 and c. $395 \mathrm{Ma}$.

We interpret the described structure as a major fluid pathway that remained active for $c .30 \mathrm{Ma}, 1 \mathrm{~km}$ above and parallel to the palaeo-subduction interface. Observed paragenesis coupled with major and trace element mineral chemistry demonstrate that this drainage collected slab-derived trondhjemitic melts. The dyke was then exploited by later fluids to penetrate the mantle wedge. This field example may perhaps be applied to other large jadeitite bodies (such as those known in Myanmar), implying formation at relatively high temperatures $\left(>700^{\circ} \mathrm{C}\right)$ in non-serpentinized lithospheric mantle, by replacement of a former felsic dyke in a hot subduction initiation environment. In Myanmar or in the Caribbean (and likely to a lesser extent in the Polar Urals), later fluid-rock interaction events may have allowed crystallization of further jadeitite-bearing rocks at much lower temperatures $\left(<500^{\circ} \mathrm{C}\right)$ with cooling of the subduction system and serpentinization of the host mantle wedge. Our results highlight the original spatial relationships between diverse lithologies such as green and white jadeitites, dark granofels and metasomatic trondhjemites, which were until now mostly reported as dismembered blocks in poorly exposed $H P$ serpentinite mélanges worldwide. We underline here the great importance of the Pus'yerka locality (Syum-Keu massif, Polar Urals) for understanding melt generation and fluid-rock interaction processes immediately above the plate interface at the inception of subduction settings.

\section{ACKNOWLEDGEMENTS}

Nicolas Rividi and Michel Fialin (CAMPARIS) are acknowledged for assistance with Electron Probe measurements and mapping. Michael Bostock is acknowledged for insightful discussions. This study was supported by the IdEx ANR-18IDEX-0001 through a chair attributed to SA. Oleg, Firaz and Katia are acknowledged for assistance during the two field expeditions. The article was prepared when working on the state budget topic IGG UB RAS AAAA-A18-118052590032-6. Two reviewers are acknowledged for constructive comments. This is IPGP contribution \#40XX.

\section{ORCID}

Samuel Angiboust (iD https://orcid. org/0000-0002-0207-2927

\section{REFERENCES}

Abers, G. A., Van Keken, P. E., \& Hacker, B. R. (2017). The cold and relatively dry nature of mantle forearcs in subduction zones. Nature Geoscience, 10(5), 333-337. https://doi.org/10.1038/ngeo2922

Agard, P., Plunder, A., Angiboust, S., Bonnet, G., \& Ruh, J. (2018). The subduction plate interface: Rock record and mechanical coupling (from long to short timescales). Lithos, 320, 537-566. https://doi. org/10.1016/j.lithos.2018.09.029

Aoya, M., Endo, S., Mizukami, T., \& Wallis, S. R. (2013). Paleo-mantle wedge preserved in the Sambagawa high-pressure metamorphic belt and the thickness of forearc continental crust. Geology, 41(4), 451454. https://doi.org/10.1130/G33834.1

Arai, S., \& Ishimaru, S. (2008). Insights into petrological characteristics of the lithosphere of mantle wedge beneath arcs through peridotite xenoliths: A review. Journal of Petrology, 49(4), 665-695. https:// doi.org/10.1093/petrology/egm069

Arai, S., Shirasaka, M., Ishida, Y., \& Inoue, H. (2019). Na-bearing tremolites as reservoirs of fluid-mobile elements in the mantle wedge: Inference from the Ochiai-Hokubo complex (Southwest Japan) in high-P schists. Journal of Mineralogical and Petrological Sciences, 181126.

Batanova, V. G., Belousov, I. A., Savelieva, G. N., \& Sobolev, A. V. (2011). Consequences of channelized and diffuse melt transport in supra-subduction zone mantle: Evidence from the Voykar ophiolite (Polar Urals). Journal of Petrology, 52(12), 2483-2521. https://doi. org/10.1093/petrology/egr053

Bebout, G. E., \& Penniston-Dorland, S. C. (2016). Fluid and mass transfer at subduction interfaces-The field metamorphic record. Lithos, 240, 228-258. https://doi.org/10.1016/j.lithos.2015.10.007

Blanco-Quintero, I. F., García-Casco, A., \& Gerya, T. V. (2011). Tectonic blocks in serpentinite mélange (eastern Cuba) reveal largescale convective flow of the subduction channel. Geology, 39(1), 79-82. https://doi.org/10.1130/G31494.1

Blanco-Quintero, I. F., Rojas-Agramonte, Y., García-Casco, A., Kröner, A., Mertz, D. F., Lázaro, C., Blanco-Moreno, J., \& Renne, P. R. (2011). Timing of subduction and exhumation in a subduction channel: Evidence from slab melts from La Corea Mélange (eastern Cuba). Lithos, 127(1-2), 86-100. https://doi.org/10.1016/j. lithos.2011.08.009

Bleek, A. W. G. (1908). Jadeite in the Kachin Hills, Upper Burma. Records of the Geological Survey India, 36(4), 254-285.

Bouilhol, P., Burg, J. P., Bodinier, J. L., Schmidt, M. W., Bernasconi, S. M., \& Dawood, H. (2012). Gem olivine and calcite mineralization precipitated from subduction-derived fluids in the Kohistan arc-mantle (Pakistan). The Canadian Mineralogist, 50(5), 12911304. https://doi.org/10.3749/canmin.50.5.1291

Brown, D., Puchkov, V., Alvarez-Marron, J., Bea, F., \& Perez-Estaun, A. (2006). Tectonic processes in the Southern and Middle Urals: An overview. Geological Society, London, Memoirs, 32(1), 407-419. https://doi.org/10.1144/GSL.MEM.2006.032.01.24

Cárdenas-Párraga, J., García-Casco, A., Harlow, G. E., Blanco-Quintero, I. F., Agramonte, Y. R., \& Kröner, A. (2012). Hydrothermal origin and age of jadeitites from Sierra del Convento Mélange (Eastern Cuba). European Journal of Mineralogy, 24(2), 313-331. https:// doi.org/10.1127/0935-1221/2012/0024-2171 
Chen, Y. I., Huang, F., Shi, G.-H., Wu, F.-Y., Chen, X. I., Jin, Q. Z., Su, B., Guo, S., Sein, K., \& Nyunt, T. T. (2018). Magnesium isotope composition of subduction zone fluids as constrained by jadeitites from Myanmar. Journal of Geophysical Research: Solid Earth, 123(9), 7566-7585. https://doi.org/10.1029/2018J B015805

Chhiber, H. L. (1934). The mineral resources of Burma. MacMillan.

Cluzel, D., Meffre, S., Maurizot, P., \& Crawford, A. J. (2006). Earliest Eocene (53 Ma) convergence in the Southwest Pacific: Evidence from pre-obduction dikes in the ophiolite of New Caledonia. Terra Nova, 18(6), 395-402.

Coleman, R. G. (1961). Jadeite deposits of the Clear Creek area, New Idria district, San Benito County, California. Journal of Petrology, 2(2), 209-247. https://doi.org/10.1093/petrology/2.2.209

Dahl, P. S. (1996). The effects of composition on retentivity of argon and oxygen in hornblende and related amphiboles: A field-tested empirical model. Geochimica et Cosmochimica Acta, 60, 36873700. https://doi.org/10.1016/0016-7037(96)00170-6

Davies, J. H. (1999). The role of hydraulic fractures and intermediate-depth earthquakes in generating subduction-zone magmatism. Nature, 398(6723), 142-145.

Dobretsov, N. L., \& Ponomareva, L. G. (1968). Comparative characteristics of jadeite and associated rocks from Polar Ural and Prebalkhash region. International Geology Review, 10(3), 247-279. https://doi. org/10.1080/00206816809474874

Dobretsov, N. L., \& Sobolev, N. V. (1984). Glaucophane schists and eclogites in the folded systems of northern Asia. Ofioliti, 9, 401-424.

Endo, S., Mizukami, T., Wallis, S. R., Tamura, A., \& Arai, S. (2015). Orthopyroxene-rich Rocks from the Sanbagawa Belt (SW Japan): Fluid-Rock Interaction in the Forearc Slab-Mantle Wedge Interface. Journal of Petrology, 56(6), 1113-1137. https://doi.org/10.1093/ petrology/egv031

Fishman, A. M. (2006). Gems in the north Ural and Timan. Geoprint, Syktyvkar, 88 pp. (in Russian).

Flores, K. E., Martens, U. C., Harlow, G. E., Brueckner, H. K., \& Pearson, N. J. (2013). Jadeitite formed during subduction: In situ zircon geochronology constraints from two different tectonic events within the Guatemala Suture Zone. Earth and Planetary Science Letters, 371, 67-81. https://doi.org/10.1016/j.epsl.2013.04.015

Flores, K. E., Skora, S., Martin, C., Harlow, G. E., Rodríguez, D., \& Baumgartner, P. O. (2015). Metamorphic history of riebeckite-and aegirine-augite-bearing high-pressure-low-temperature blocks within the Siuna Serpentinite Mélange, northeastern Nicaragua. International Geology Review, 57(5-8), 943-977. https://doi. org/10.1080/00206814.2015.1027747

Freeman, S. R., Butler, R. W. H., Cliff, R. A., \& Rex, D. C. (1998). Dating mylonite evolution: A Rb-Sr and K-Ar study of the Moine mylonites. Journal of the Geological Society, London, 155, 745-758.

Fu, B., Valley, J. W., Kita, N. T., Spicuzza, M. J., Paton, C., Tsujimori, T., Bröcker, M., \& Harlow, G. E. (2010). Multiple origins of zircons in jadeitite. Contributions to Mineralogy and Petrology, 159(6), 769-780. https://doi.org/10.1007/s00410-009-0453-y

Fumagalli, P., Poli, S., Fischer, J., Merlini, M., \& Gemmi, M. (2014). The high-pressure stability of chlorite and other hydrates in subduction mélanges: Experiments in the system $\mathrm{Cr}_{2} \mathrm{O}_{3}-\mathrm{MgO}-\mathrm{Al}_{2} \mathrm{O}_{3}-$ $\mathrm{SiO}_{2}-\mathrm{H}_{2} \mathrm{O}$. Contributions to Mineralogy and Petrology, 167(2), 979. https://doi.org/10.1007/s00410-014-0979-5

García-Casco, A. (2007). Magmatic paragonite in trondhjemites from the Sierra del Convento mélange, Cuba. American Mineralogist, 92(7), 1232-1237.
Garcia-Casco, A., Knippenberg, S., Ramos, R. R., Harlow, G. E., Hofman, C., Pomo, J. C., \& Blanco-Quintero, I. F. (2013). PreColumbian jadeitite artifacts from the Golden Rock Site, St. Eustatius, Lesser Antilles, with special reference to jadeitite artifacts from Elliot's, Antigua: Implications for potential source regions and long-distance exchange networks in the Greater Caribbean. Journal of Archaeological Science, 40(8), 3153-3169.

García-Casco, A., Lázaro, C., Rojas-Agramonte, Y., Kröner, A., TorresRoldán, R. L., Núñez, K., \& Blanco-Quintero, I. (2008). Partial melting and counterclockwise P-T path of subducted oceanic crust (Sierra del Convento mélange, Cuba). Journal of Petrology, 49(1), 129-161.

García-Casco, A., Rodríguez Vega, A., Cárdenas Párraga, J., IturraldeVinent, M. A., Lázaro, C., Blanco Quintero, I., Rojas Agramonte, Y., Kröner, A., Núñez Cambra, K., Millán, G., Torres-Roldán, R. L., \& Carrasquilla, S. (2009). A new jadeitite jade locality (Sierra del Convento, Cuba): First report and some petrological and archeological implications. Contributions to Mineralogy and Petrology, 158(1), 1. https://doi.org/10.1007/s00410-008-0367-0

Gerya, T. V., Stöckhert, B., \& Perchuk, A. L. (2002). Exhumation of high-pressure metamorphic rocks in a subduction channel: A numerical simulation. Tectonics, 21(6), 6-1. https://doi.org/10.1029/2002T C001406

Glodny, J., Austrheim, H., Molina, J. F., Rusin, A. I., \& Seward, D. (2003). $\mathrm{Rb} / \mathrm{Sr}$ record of fluid-rock interaction in eclogites: The Marun-Keu complex, Polar Urals, Russia. Geochimica Et Cosmochimica Acta, 67(22), 4353-4371. https://doi.org/10.1016/ S0016-7037(03)00370-3

Glodny, J., Kühn, A., \& Austrheim, H. (2008). Diffusion versus recrystallization processes in $\mathrm{Rb}-\mathrm{Sr}$ geochronology: Isotopic relics in eclogite facies rocks, Western Gneiss Region, Norway. Geochimica et Cosmochimica Acta, 72(2), 506-525. https://doi.org/10.1016/j. gca.2007.10.021

Glodny, J., Pease, V., Montero, P., Austrheim, H., \& Rusin, A. I. (2004). Protolith ages of eclogites, Marun-Keu Complex, Polar Urals, Russia: Implications for the pre-and early Uralian evolution of the northeastern European continental margin. Geological Society, London, Memoirs, 30(1), 87-105. https://doi.org/10.1144/GSL. MEM.2004.030.01.09

Green, E., Holland, T., \& Powell, R. (2007). An order-disorder model for omphacitic pyroxenes in the system jadeite-diopside-hedenbergite-acmite, with applications to eclogitic rocks. American Mineralogist, 92(7), 1181-1189. https://doi.org/10.2138/ am.2007.2401

Grégoire, M., Jégo, S., Maury, R. C., Polvé, M., Payot, B., Tamayo, R. A. Jr, \& Yumul, G. P. Jr (2008). Metasomatic interactions between slab-derived melts and depleted mantle: Insights from xenoliths within Monglo adakite (Luzon arc, Philippines). Lithos, 103(3-4), 415-430. https://doi.org/10.1016/j.lithos.2007.10.013

Grove, T. L., Till, C. B., \& Krawczynski, M. J. (2012). The role of $\mathrm{H}_{2} \mathrm{O}$ in subduction zone magmatism. Annual Review of Earth and Planetary Sciences, 40, 413-439.

Guillot, S., Hattori, K. H., de Sigoyer, J., Nägler, T., \& Auzende, A. L. (2001). Evidence of hydration of the mantle wedge and its role in the exhumation of eclogites. Earth and Planetary Science Letters, 193(1-2), 115-127. https://doi.org/10.1016/S0012-821X(01)00490 $-3$

Halpaap, F., Rondenay, S., Perrin, A., Goes, S., Ottemöller, L., Austrheim, H., Shaw, R., \& Eeken, T. (2019). Earthquakes track 
subduction fluids from slab source to mantle wedge sink. Science. Advances, 5(4), eaav7369. https://doi.org/10.1126/sciadv.aav7369

Harlow, G. E. (1994). Jadeitites, albitites and related rocks from the Motagua Fault Zone, Guatemala. Journal of Metamorphic Geology, 12(1), 49-68. https://doi.org/10.1111/j.1525-1314.1994. tb00003.x

Harlow, G. E., Flores, K. E., \& Marschall, H. R. (2016). Fluid-mediated mass transfer from a paleosubduction channel to its mantle wedge: Evidence from jadeitite and related rocks from the Guatemala Suture Zone. Lithos, 258, 15-36. https://doi.org/10.1016/j. lithos.2016.04.010

Harlow, G. E., \& Sorensen, S. S. (2005). Jade (nephrite and jadeitite) and serpentinite: Metasomatic connections. International Geology Review,47(2),113-146.https://doi.org/10.2747/0020-6814.47.2.113

Harlow, G. E., Tsujimori, T., \& Sorensen, S. S. (2015). Jadeitites and plate tectonics. Annual Review of Earth and Planetary Sciences, 43, 105-138. https://doi.org/10.1146/annurev-earth-060614-105215

Hawthorne, F. C., \& Oberti, R. (2007). Classification of the amphiboles. Reviews in Mineralogy and Geochemistry, 67(1), 55-88. https://doi. org/10.2138/rmg.2007.67.2

Hellstrom, J., Paton, C., Woodhead, J., \& Hergt, J. (2008). Iolite: Software for spatially resolved LA-(quad and MC) ICPMS analysis. Mineralogical Association of Canada Short Course Series, 40, 343-348.

Hertwig, A., McClelland, W. C., Kitajima, K., Schertl, H.-P., Maresch, W. V., Stanek, K., Valley, J. W., \& Sergeev, S. A. (2016). Inherited igneous zircons in jadeitite predate high-pressure metamorphism and jadeitite formation in the Jagua Clara serpentinite mélange of the Rio San Juan Complex (Dominican Republic). Contributions to Mineralogy and Petrology, 171(5), 48. https://doi.org/10.1007/ s00410-016-1256-6

Hopp, J., Trieloff, M., Brey, G. P., Woodland, A. B., Simon, N. S. C., Wijbrans, J. R., Siebel, W., \& Reitter, E. (2008). 40Ar/39Ar-ages of phlogopite in mantle xenoliths from South African kimberlites: Evidence for metasomatic mantle impregnation during the Kibaran orogenic cycle. Lithos, 106(3-4), 351-364. https://doi.org/10.1016/j. lithos.2008.09.001

Howe, H., Pawley, A. R., \& Welch, M. D. (2018). Sodium amphibole in the post-glaucophane high-pressure domain: The role of eckermannite. American Mineralogist, 103(6), 989-992. https://doi. org/10.2138/am-2018-6399

Hyndman, R. D., \& Peacock, S. M. (2003). Serpentinization of the forearc mantle. Earth and Planetary Science Letters, 212(3-4), 417-432. https://doi.org/10.1016/S0012-821X(03)00263-2

Hyppolito, T., Cambeses, A., Angiboust, S., Raimondo, T., GarcíaCasco, A., \& Juliani, C. (2018). Rehydration of eclogites and garnet-replacement processes during exhumation in the amphibolite facies. Geological Society, London, Special Publications, 478(SP478), 473. https://doi.org/10.1144/sp478.3

Inger, S., \& Cliff, R. A. (1994). Timing of metamorphism in the Tauern Window, Eastern Alps: Rb-Sr ages and fabric formation. Journal of Metamorphic Geology, 12(5), 695-707. https://doi. org/10.1111/j.1525-1314.1994.tb00052.x

Ishizuka, H. (1980). Soda-tremolite-bearing dunite from the Horokanai ophiolite in the Kamuikotan tectonic belt, Hokkaido, Japan. The Journal of the Japanese Association of Mineralogists, Petrologists and Economic Geologists, 75(11), 372-376. https://doi.org/10.2465/ ganko1941.75.372

Ivanov, K. S. (2001). Estimation of paleovelocities of subduction and collision during the formation of the Urals. Doklady Earth Sciences, 377(2), 164-167. (in Russian)
Iwao, S. (1953). Albitite and associated jadeite rock from Kotaki District, Japan: Study in ceramic raw material. Reports, Geological Survey of Japan, 153, 1-25.

Jochum, K. P., Wilson, S. A., Abouchami, W., Amini, M., Chmeleff, J., Eisenhauer, A., Hegner, E., Iaccheri, L. M., Kieffer, B., Krause, J., McDonough, W. F., Mertz-Kraus, R., Raczek, I., Rudnick, R. L., Scholz, D., Steinhoefel, G., Stoll, B., Stracke, A., Tonarini, S., \& Woodhead, J. D. (2011). GSD-1G and MPI-DING reference glasses for in situ and bulk isotopic determination. Geostandards and Geoanalytical Research, 35, 193-226. https:// doi.org/10.1111/j.1751-908X.2010.00114.X

Kawamoto, T., Hertwig, A., Schertl, H. P., \& Maresch, W. V. (2018). Fluid inclusions in jadeitite and jadeite-rich rock from serpentinite mélanges in northern Hispaniola: Trapped ambient fluids in a cold subduction channel. Lithos, 308, 227-241. https://doi.org/10.1016/j. lithos.2018.02.024

Kazak, A. P., Dobretsov, N. L., \& Moldavantsev, J. E. (1976). Glaucophane schists, jadeitites, vesuvianites and nephrites of the Rai-Iz ultramafic massif. Geology and Geophysics, 2, 60-66. (in Russian)

Kepezhinskas, P. K., Defant, M. J., \& Drummond, M. S. (1995). Nametasomatism in the island-arc mantle by slab melt-Peridotite interaction: Evidence from mantle xenoliths in the North Kamchatka Arc. Journal of Petrology, 36(6), 1505-1527.

Konovalov, A. L., \& Sergeev, S. S. (2015). About the age of zircons from jadeitite ultrabasite array of Syomke in the zone of the Main Uralian fault (the Polar Urals). Regionalnaya Geologiya I Metallogeniya., 64, 41-47. (in Russian).

Koppers, A. A. (2002). ArArCALC - software for 40Ar/39Ar age calculations. Computers \& Geosciences, 28(5), 605-619. https://doi. org/10.1016/S0098-3004(01)00095-4

Korzinski, D. S. (1959). Physicochemical basis of the analysis of the paragenesis of minerals. Consultants Bureau, $142 \mathrm{pp}$.

Krebs, M., Schertl, H. P., Maresch, W. V., \& Draper, G. (2011). Mass flow in serpentinite-hosted subduction channels: P-T-t path patterns of metamorphic blocks in the Rio San Juan mélange (Dominican Republic). Journal of Asian Earth Sciences, 42(4), 569-595. https:// doi.org/10.1016/j.jseaes.2011.01.011

Kugimiya, Y., \& Takasu, A. (2002). Geology of the Western Iratsu mass within the tectonic melange zone in the Sambagawa metamorphic belt, Besshi district, central Shikoku, Japan. The Journal of the Geological Society of Japan, 108(10), 644-662. https://doi. org/10.5575/geosoc.108.10_644

Kühn, A., Glodny, J., Iden, K., \& Austrheim, H. (2000). Retention of Precambrian $\mathrm{Rb} / \mathrm{Sr}$ phlogopite ages through Caledonian eclogite facies metamorphism, Bergen Arc complex, W-Norway. Lithos, 51(4), 305-330. https://doi.org/10.1016/S0024-4937(99)00067-5

Kuznetsov, Y. V., Kuznetsova, N. A., \& Tsyutskiy, S. S. (1986). Features of jadeite mineralization in the Pus'yerka deposit (Polar Urals). International Geology Review, 28(9), 1096-1101. https://doi. org/10.1080/00206818609466352

Lacroix, A. (1930). La jadeite de Birmanie: Les roches qu'elle constitue ou qui l'accompagnent. Composition et Origine. Bulletin De Minéralogie, 53(1), 216-254.

Lázaro, C., Blanco-Quintero, I. F., Marchesi, C., Bosch, D., RojasAgramonte, Y., \& García-Casco, A. (2011). The imprint of subduction fluids on subducted MORB-derived melts (Sierra del Convento Mélange, Cuba). Lithos, 126(3-4), 341-354. https://doi. org/10.1016/j.lithos.2011.07.011

Lázaro, C., \& García-Casco, A. (2008). Geochemical and Sr-Nd isotope signatures of pristine slab melts and their residues (Sierra del 
Convento mélange, eastern Cuba). Chemical Geology, 255(1-2), 120-133. https://doi.org/10.1016/j.chemgeo.2008.06.017

Lázaro, C., Garcia-Casco, A., Rojas Agramonte, Y., Kröner, A., Neubauer, F., \& Iturralde-Vinent, M. (2009). Fifty-five-millionyear history of oceanic subduction and exhumation at the northern edge of the Caribbean plate (Sierra del Convento mélange, Cuba). Journal of Metamorphic Geology, 27(1), 19-40. https://doi. org/10.1111/j.1525-1314.2008.00800.x

Lee, J. Y., Marti, K., Severinghaus, J. P., Kawamura, K., Yoo, H. S., Lee, J. B., \& Kim, J. S. (2006). A redetermination of the isotopic abundances of atmospheric Ar. Geochimica et Cosmochimica Acta, 70(17), 4507-4512. https://doi.org/10.1016/j.gca.2006.06.1563

Lei, W., Shi, G., Santosh, M., Ng, Y., Liu, Y., Wang, J., Xie, G., \& Ju, Y. (2016). Trace element features of hydrothermal and inherited igneous zircon grains in mantle wedge environment: A case study from the Myanmar jadeitite. Lithos, 266, 16-27. https://doi.org/10.1016/j. lithos.2016.09.031

Liu, Y. Y., Perchuk, A. L., \& Philippot, P. (2019). Eclogites from the Marun-Keu Complex, Polar Urals, Russia: A record of hot subduction and sub-isothermal exhumation. Geological Society, London, Special Publications, 474(1), 255-274. https://doi.org/10.1144/ SP474.6

Ludwig, K. (2009). Isoplot v. 3.71: A geochronological toolkit for Microsoft Excel: Berkeley, California. Berkeley Geochronology Center Special Publication, 4, 70.

Makeyev, A. B. (1992). Mineralogy of alpine-type ultramafics in the Ural. Nauka, St. Petersburg, 195 p. (in Russian).

Manning, C. E. (2004). The chemistry of subduction-zone fluids. Earth and Planetary Science Letters, 223(1-2), 1-16. https://doi. org/10.1016/j.eps1.2004.04.030

Meng, F., Fan, Y., Shmelev, V. R., \& Kulikova, K. V. (2020). Constraints of eclogites from the Marun-Keu metamorphic complex on the tectonic history of the Polar Urals (Russia). Journal of Asian Earth Sciences, 187, 104087. https://doi.org/10.1016/j. jseaes.2019.104087

Meng, F., Makeyev, A. B., \& Yang, J. (2011). Zircon U-Pb dating of jadeitite from the Syum-Keu ultramafic complex, Polar Urals, Russia: Constraints for subduction initiation. Journal of Asian Earth Sciences, 42(4), 596-606. https://doi.org/10.1016/j. jseaes.2011.01.013

Meng, F., Yang, H. J., Makeyev, A. B., Ren, Y., Kulikova, K. V., \& Bryanchaninova, N. I. (2016). Jadeitite in the Syum-Keu ultramafic complex from Polar Urals, Russia: Insights into fluid activity in subduction zones. European Journal of Mineralogy, 28(6), 1079-1097. https://doi.org/10.1127/ejm/2016/0028-2563

Menold, C. A., Grove, M., Sievers, N. E., Manning, C. E., Yin, A., Young, E. D., \& Ziegler, K. (2016). Argon, oxygen, and boron isotopic evidence documenting 40ArE accumulation in phengite during water-rich high-pressure subduction metasomatism of continental crust. Earth and Planetary Science Letters, 446, 56-67. https://doi. org/10.1016/j.eps1.2016.04.010

Mével, C., \& Kienast, J. R. (1986). Jadeite-kosmochlor solid solution and chromian sodic amphiboles in jadeitites and associated rocks from Tawmaw (Burma). Bulletin De Minéralogie, 109(6), 617-633. https://doi.org/10.3406/bulmi.1986.7964

Molina, J. F., Austrheim, H., Glodny, J., \& Rusin, A. (2002). The eclogites of the Marun-Keu complex, Polar Urals (Russia): Fluid control on reaction kinetics and metasomatism during high $\mathrm{P}$ metamorphism. Lithos, 61(1-2), 55-78. https://doi.org/10.1016/S0024 $-4937(02) 00070-1$
Morimoto, N. (1989). Nomenclature of pyroxenes. Mineralogical Journal, 14(5), 198-221. https://doi.org/10.2465/minerj.14.198

Morishita, T., Arai, S., \& Ishida, Y. (2007). Trace element compositions of jadeite (+ omphacite) in jadeitites from the Itoigawa-Ohmi district, Japan: Implications for fluid processes in subduction zones. Island Arc, 16(1), 40-56. https://doi. org/10.1111/j.1440-1738.2007.00557.x

Newton, R. C., \& Manning, C. E. (2010). Role of saline fluids in deepcrustal and upper-mantle metasomatism: Insights from experimental studies. Geofluids, 10(1-2), 58-72.

Ni, H., Zhang, L., Xiong, X., Mao, Z., \& Wang, J. (2017). Supercritical fluids at subduction zones: Evidence, formation condition, and physicochemical properties. Earth-Science Reviews, 167, 62-71. https://doi.org/10.1016/j.earscirev.2017.02.006

Nyunt, T. T., Massonne, H. J., \& Sun, T. T. (2017). Jadeitite and other high-pressure metamorphic rocks from the Jade Mines Belt, Tawmaw area, Kachin State, northern Myanmar. Geological Society, London, Memoirs, 48(1), 295-315.

Padrón-Navarta, J. A., Sánchez-Vizcaíno, V. L., Hermann, J., Connolly, J. A., Garrido, C. J., Gómez-Pugnaire, M. T., \& Marchesi, C. (2013). Tschermak's substitution in antigorite and consequences for phase relations and water liberation in high-grade serpentinites. Lithos, 178, 186-196. https://doi.org/10.1016/j.lithos.2013.02.001

Paton, C., Hellstrom, J., Paul, B., Woodhead, J., \& Hergt, J. (2011). Iolite: Freeware for the visualisation and processing of mass spectrometric data. Journal of Analytical Atomic Spectrometry, 26(12), 2508-2518. https://doi.org/10.1039/c1ja10172b

Pearce, N. J. G., Perkins, W. T., Westgate, J. A., Gorton, M. P., Jackson, S. E., Neal, C. R., \& Chenery, S. P. (1997). A compilation of new and published major and trace element data for NIST SRM 610 and NIST SRM 612 glass reference materials. Geostandards Newsletter - Journal of Geostandards and Geoanalysis, 21(1), 115-144. https://doi.org/10.1111/j.1751-908X.1997.tb00538.x

Pirard, C., \& Hermann, J. (2015). Experimentally determined stability of alkali amphibole in metasomatised dunite at sub-arc pressures. Contributions to Mineralogy and Petrology, 169(1), 1. https://doi. org/10.1007/s00410-014-1095-2

Poli, S., \& Schmidt, M. W. (2002). Petrology of subducted slabs. Annual Review of Earth and Planetary Sciences, 30(1), 207-235. https:// doi.org/10.1146/annurev.earth.30.091201.140550

Prigent, C., Guillot, S., Agard, P., Lemarchand, D., Soret, M., \& Ulrich, M. (2018). Transfer of subduction fluids into the deforming mantle wedge during nascent subduction: Evidence from trace elements and boron isotopes (Semail ophiolite, Oman). Earth and Planetary Science Letters, 484, 213-228. https://doi.org/10.1016/j. eps1.2017.12.008

Puchkov, V. N. (2009). The diachronous (step-wise) arc-continent collision in the Urals. Tectonophysics, 479(1-2), 175-184. https://doi. org/10.1016/j.tecto.2009.01.014

Putnis, A. (2009). Mineral replacement reactions. Reviews in Mineralogy and Geochemistry, 70(1), 87-124. https://doi.org/10.2138/ rmg.2009.70.3

Putnis, A., \& John, T. (2010). Replacement processes in the Earth's crust. Elements, 6(3), 159-164. https://doi.org/10.2113/gselements.6.3.159

Queiroga, G., Martins, M., Kuznetsov, N., Chemale, F., Dussin, I., PedrosaSoares, A. C., \& de Castro, M. P. (2016). Timing of lower crust generations in the Voykar ophiolite massif, Polar Urals, Russia: U-Pb LAICPS-MS) data from plagiogranite zircons. Ofioliti, 41(2), 75-84.

Raimondo, T., Payne, J., Wade, B., Lanari, P., Clark, C., \& Hand, M. (2017). Trace element mapping by LA-ICP-MS: Assessing 
geochemical mobility in garnet. Contributions to Mineralogy and Petrology, 172(4), 17. https://doi.org/10.1007/s00410-017-1339-z

Rapp, R. P., Watson, E. B., \& Miller, C. F. (1991). Partial melting of amphibolite/eclogite and the origin of Archean trondhjemites and tonalites. Precambrian Research, 51(1-4), 1-25. https://doi. org/10.1016/0301-9268(91)90092-O

Rubatto, D., \& Hermann, J. (2003). Zircon formation during fluid circulation in eclogites (Monviso, Western Alps): Implications for $\mathrm{Zr}$ and Hf budget in subduction zones. Geochimica et Cosmochimica Acta, 67(12), 2173-2187. https://doi.org/10.1016/S0016-7037(02)01321 $-2$

Rüpke, L. H., Morgan, J. P., Hort, M., \& Connolly, J. A. (2004). Serpentine and the subduction zone water cycle. Earth and Planetary Science Letters, 223(1-2), 17-34. https://doi.org/10.1016/j.epsl.2004.04.018

Safonov, O. G., \& Butvina, V. G. (2016). Indicator reactions of K and $\mathrm{Na}$ activities in the upper mantle: Natural mineral assemblages, experimental data, and thermodynamic modeling. Geochemistry International, 54(10), 858-872. https://doi.org/10.1134/S0016 702916100098

Savelieva, G. N., Batanova, V. G., \& Sobolev, A. V. (2016). PyroxeneCr-spinel exsolution in mantle lherzolites of the Syum-Keu ophiolite massif (Arctic Urals). Russian Geology and Geophysics, 57(10), 1419-1436. https://doi.org/10.1016/j.rgg.2015.12.001

Savelieva, G. N., Sharaskin, A. Y., Saveliev, A. A. et al (2002). Ophiolites and zoned mafic-ultramafic massifs of the Urals: A comparative analysis and some tectonic implications. Mountain Building in the Uralides, 135-153.

Savelieva, G. N., \& Suslov, P. V. (2014). Structure and composition of mantle peridotites at the boundary with crustal complexes of ophiolites in the Syumkeu massif, Polar Urals. Geotectonics, 48(5), 347358. https://doi.org/10.1134/S0016852114040074

Savelieva, G. N., Suslov, P. V., \& Larionov, A. N. (2007). Vendian Tectono-magmatic events in mantle ophiolitic complexes of the Polar Urals: U-Pb dating of zircon from chromitite. Geotectonics, 41(2), 105-113. https://doi.org/10.1134/S0016852107020021

Scambelluri, M., Cannaò, E., \& Gilio, M. (2019). The water and fluid-mobile element cycles during serpentinite subduction. A review. European Journal of Mineralogy, 31(3), 405-428. https://doi. org/10.1127/ejm/2019/0031-2842

Schmidt, M. W., \& Poli, S. (2004). Magmatic epidote. Reviews in Mineralogy and Geochemistry, 56(1), 399-430. https://doi. org/10.2138/gsrmg.56.1.399

Schmidt, M., \& Poli, S. (2014). Devolatilization during subduction. The Crust. Treatise on Geochemistry, 4(19).

Schneider, M. E., \& Eggler, D. H. (1986). Fluids in equilibrium with peridotite minerals: Implications for mantle metasomatism. Geochimica et Cosmochimica Acta, 50(5), 711-724. https://doi. org/10.1016/0016-7037(86)90347-9

Selyatitskii, A. Y., \& Kulikova, K. V. (2017). The first evidence of UHP metamorphism in the Polar Urals (Russia). Doklady Earth Sciences, 476(2), 1222-1225. https://doi.org/10.1134/S1028334X17100270

Shatsky, V. S., Simonov, V. A., Jagoutz, E., Koz'menko, O. A., \& Kurenkov, S. A. (2000). New data on the age of eclogites from the Polar Urals. Doklady Earth Sciences, 371A, 534-538.

Shi, G. H., Cui, W. Y., Tropper, P., Wang, C. Q., Shu, G. M., \& Yu, H. (2003). The petrology of a complex sodic and sodic-calcic amphibole association and its implications for the metasomatic processes in the jadeitite area in northwestern Myanmar, formerly Burma. Contributions to Mineralogy and Petrology, 145(3), 355-376. https://doi.org/10.1007/s00410-003-0457-y
Shi, G., Harlow, G. E., Wang, J., Wang, J., Enoch, N. G., Wang, X., Cao, S. M., \& Enyuancui, W. (2012). Mineralogy of jadeitite and related rocks from Myanmar: A review with new data. European Journal of Mineralogy, 24(2), 345-370. https://doi. org/10.1127/0935-1221/2012/0024-2190

Shi, G. H., Stöckhert, B., \& Cui, W. Y. (2005). Kosmochlor and chromian jadeite aggregates from the Myanmar jadeitite area. Mineralogical Magazine, 69(6), 1059-1075. https://doi.org/10.1180/0026461056 960308

Shimizu, Y., Arai, S., Morishita, T., Yurimoto, H., \& Gervilla, F. (2004). Petrochemical characteristics of felsic veins in mantle xenoliths from Tallante (SE Spain): An insight into activity of silicic melt within the mantle wedge. Earth and Environmental Science Transactions of the Royal Society of Edinburgh, 95(1-2), 265-276. https://doi. org/10.1017/S0263593300001061

Shmelev, V. R. (2011). Mantle ultrabasites of ophiolite complexes in the Polar Urals: Petrogenesis and geodynamic environments. Petrology, 19(6), 618-640. https://doi.org/10.1134/S0869591111060038

Sorensen, S. S., Sisson, V. B., Harlow, G. E., \& Avé Lallemant, H. G. (2010). Element residence and transport during subduction-zone metasomatism: Evidence from a jadeitite-serpentinite contact, Guatemala. International Geology Review, 52(9), 899-940. https:// doi.org/10.1080/00206810903211963

Soret, M., Agard, P., Dubacq, B., Vitale-Brovarone, A., Monié, P., Chauvet, A., Whitechurch, H., \& Villemant, B. (2016). Strain localization and fluid infiltration in the mantle wedge during subduction initiation: Evidence from the base of the New Caledonia ophiolite. Lithos, 244, 1-19. https://doi.org/10.1016/j. lithos.2015.11.022

Spandler, C., Hermann, J., Faure, K., Mavrogenes, J. A., \& Arculus, R. J. (2008). The importance of talc and chlorite "hybrid" rocks for volatile recycling through subduction zones; evidence from the high-pressure subduction mélange of New Caledonia. Contributions to Mineralogy and Petrology, 155(2), 181-198. https://doi. org/10.1007/s00410-007-0236-2

Spandler, C., \& Pirard, C. (2013). Element recycling from subducting slabs to arc crust: A review. Lithos, 170, 208-223. https://doi. org/10.1016/j.lithos.2013.02.016

Spear, F. S. (1993). Metamorphic phase equilibria and pressure-temperature-time-paths. Mineralogical Society of America Monograph.

Stampfli, G. M., von Raumer, J. F., \& Borel, G. D. (2002). Paleozoic evolution of pre-Variscan terranes: From Gondwana to the Variscan collision. Special Papers-Geological Society of America, 364, 263-280.

Sychev, S. N., \& Kulikova, K. V. (2012). Structural evolution of the Main Ural Fault Zone in the western framework of the VoikarSynya ophiolite massif. Geotectonics, 46(6), 427-434. https://doi. org/10.1134/S0016852112050056

Tamblyn, R., Zack, T., Schmitt, A. K., Hand, M., Kelsey, D., Morrissey, L., Pabst, S., \& Savov, I. P. (2019). Blueschist from the Mariana forearc records long-lived residence of material in the subduction channel. Earth and Planetary Science Letters, 519, 171-181. https:// doi.org/10.1016/j.eps1.2019.05.013

Torres-Roldan, R. L., Garcia-Casco, A., \& Garcia-Sanchez, P. A. (2000). CSpace: An integrated workplace for the graphical and algebraic analysis of phase assemblages on 32-bit Wintel platforms. Computers \& Geosciences, 26(7), 779-793. https://doi.org/10.1016/ S0098-3004(00)00006-6

Tsujimori, T., \& Harlow, G. E. (2012). Petrogenetic relationships between jadeitite and associated high-pressure and low-temperature 
metamorphic rocks in worldwide jadeitite localities: A review. European Journal of Mineralogy, 24(2), 371-390. https://doi. org/10.1127/0935-1221/2012/0024-2193

Tsujimori, T., Liou, J. G., Coleman, R. G., Cloos, M., Carlson, W. D., Gilbert, M. C., \& Sorensen, S. S. (2007). Finding of high-grade tectonic blocks from the New Idria serpentinite body, Diablo Range, California: Petrologic constraints on the tectonic evolution of an active serpentinite diapir. Special Papers-Geological Society of America, 419, 67.

Tsujimori, T., Liou, J. G., Wooden, J., \& Miyamoto, T. (2005). U-Pb dating of large zircons in low-temperature jadeitite from the Osayama serpentinite mélange, southwest Japan: Insights into the timing of serpentinization. International Geology Review, 47(10), 1048-1057. https://doi.org/10.2747/0020-6814.47.10.1048

Udovkina, N. G. (1971). Eclogites of Polar Urals. : Nauka(in Russian).

Vakhrusheva, N. V., \& Ivanov, K. S. (2018). The nature and age of plagioclase of the ultrabasic massif Rai-Iz (Polar Ural). Doklady Earth Sciences (in Russian), 480(1), 80-84.

Villa, I. M. (2010). Disequilibrium textures versus equilibrium modelling: Geochronology at the crossroads. Geological Society, London, Special Publications, 332(1), 1-15. https://doi.org/10.1144/SP332.1

Villa, I. M., De Bièvre, P., Holden, N. E., \& Renne, P. R. (2015). IUPAC-IUGS recommendation on the half life of ${ }^{87} \mathrm{Rb}$. Geochimica et Cosmochimica Acta, 164, 382-385. https://doi.org/10.1016/j. gca.2015.05.025

Whitney, D. L., \& Evans, B. W. (2010). Abbreviations for names of rock-forming minerals. American Mineralogist, 95(1), 185-187. https://doi.org/10.2138/am.2010.3371

Woodhead, J. D., Hellstrom, J., Hergt, J. M., Greig, A., \& Maas, R. (2007). Isotopic and elemental imaging of geological materials by laser ablation inductively coupled plasma-mass spectrometry. Geostandards and Geoanalytical Research, 31(4), 331-343.

Worzewski, T., Jegen, M., Kopp, H., Brasse, H., \& Castillo, W. T. (2011). Magnetotelluric image of the fluid cycle in the Costa Rican subduction zone. Nature Geoscience, 4(2), 108-111. https://doi. org/10.1038/ngeo1041

Wunder, B., \& Schreyer, W. (1997). Antigorite: High-pressure stability in the system MgO-SiO- $\mathrm{H}_{2} \mathrm{O}$ (MSH). Lithos, 41(1-3), 213-227.

Yui, T.-F., Maki, K., Wang, K.-L., Lan, C.-Y., Usuki, T., Iizuka, Y., Wu, C.-M., Wu, T.-W., Nishiyama, T., Martens, U., Liou, J. G., \& Grove, M. (2012). Hf isotope and REE compositions of zircon from jadeitite (Tone, Japan and north of the Motagua fault, Guatemala): Implications on jadeitite genesis and possible protoliths. European Journal of Mineralogy, 24(2), 263-275. https://doi. org/10.1127/0935-1221/2011/0023-2127

\section{SUPPORTING INFORMATION}

Additional supporting information may be found online in the Supporting Information section.
Table S1. Bulk-rock major elements composition table for serpentinites and associated metasomatic rocks from the Pus'yerka locality.

Table S2. Full Rb-Sr isotopic data set.

Table S3. ${ }^{39} \mathrm{Ar}-{ }^{40} \mathrm{Ar}$ geochronological results.

Figure S1. Optical microscope pictures of (a) an omphacite-bearing vein opened in a white jadeitite, with voids (possibly former fluid inclusions) partly filled by zeolites. (b) A representative foliated metasomatic Phl-bearing dark granofels. (c) A dark granofels. (d) A weakly serpentinized dunite from the host peridotites.

Figure S2. (a) and (b) SEM BSE picture of an omphacite-bearing vein with possibly former fluid pockets, partly filled by zeolites. (c) SEM BSE picture showing the representative matrix of a phlogopite schist. (d) X-ray maps showing the $\mathrm{Al}_{2} \mathrm{O}_{3}, \mathrm{Cr}_{2} \mathrm{O}_{3}$ and $\mathrm{Na}_{2} \mathrm{O}$ contents of a cluster of amphiboles from a dark granofels. (e) SEM BSE picture showing how the edenite crystals were fractured and filled by an omphacite-rich clinopyroxene. They are also rimmed by an amphibole with an eckermannitic composition. (f) SEM BSE picture showing a pseudomorph after a primary clinopyroxene in a matrix fully recrystallized by omphacite and phlogopite. (g) Al, K, Na and Ca X-ray maps (counts) showing major element distribution in the area of the coronitic paragonite crystal from Figure 3a (sample PU3, processed with DWImager).

Figure S3. Additional probe and LA-ICP-MS maps (sample PU2).

Figure S4. Comparison of dark granofels major element composition (data from Table S1) with respect to jadeitite and host ultramafics.

How to cite this article: Angiboust S, Glodny J, Cambeses A, et al. Drainage of subduction interface fluids into the forearc mantle evidenced by a pristine jadeitite network (Polar Urals). J. Metamorph. Geol.2021;39:473-500. https://doi.org/10.1111/ jimg. 12570 